\title{
AN INDEPENDENT JUDICIARY: THE COLONIAL BACKGROUND
}

\author{
JOSEPH H. SMITH†
}

\section{INTRODUCTION}

The origins of the American Revolution can be traced to many and varied grievances and complaints on the part of the colonists. ${ }^{1}$ The continuing controversy over independence of the judiciary in the colonies involved two aspects of colonial administration which were thought to evidence unconstitutional and unconscionable conduct by the King and by Parliament. First, the Crown rigidly adhered to the policy that judges in the royal colonies, and even in proprietary Pennsylvania, should hold office during pleasure, durante bene placito, rather than during good behavior, quam diu se bene gesserint. This policy was carried out largely by royal instructions to colonial Governors, disobedience of which could result in dismissal, and by royal disallowance of colonial acts of assembly providing for judicial tenure during good behavior. ${ }^{2}$ Second, the ministry decided in 1772 to implement the provisions of the Townshend Revenue Act of $1767^{3}$ by paying the salaries of the Superior Court judges in Massachusetts Bay. This not only made these judges independent of the popular branch of the legislature, but also, in the opinion of most patriotic colonials, provided the funds by an unconstitutional exercise of the taxing power of Parliament. ${ }^{4} \mathrm{By}$

$\uparrow$ George Welwood Murray Professor of Legal History, Columbia University. A.B. 1935, Yale University; LL.B. 1938, Columbia University.

${ }^{1}$ See generally, e.g., B. Knollenberg, Origin of the American Revolution, 1759-1766 (1960); J.A. Braeman, The Road to Independence: A Documentary History of the Causes of the American Revolution: 1763-1776 (1963); P. Maier, From Resistance to Revolution: Colonial Radicals and the Development of American Opposition to Britain 1765-1776 (1972); B. KNollenberg, Growth of THE American Revolution, 1766-1775, passim (1975).

${ }^{2}$ For general discussions see L.W. Labaree, Royal Government in America 388-401 (I958); O.M. Dickerson, American Colonial Government 195-209 (1962); 1 Pamphlets of the American Revolution, 1750-1776, at 249-55 (B. Bailyn ed. 1965).

37 Geo. 3, c. 46 (1767), as amended $10 \mathrm{Geo} .3$, c. 17 (1770). In its original form the act imposed duties on tea, glass, paper, and certain other articles shipped to the colonies; the 1770 amendment retained only the tax on tea.

${ }^{4}$ For discussions see 12 L. Gipson, The British Empire Before the Revo- 
the time of the Revolution, the original struggle against the royal prerogative, based on the rights of the colonists as English subjects under the common law and under the Act of Settlement of $1701,{ }^{5}$ had developed into a more general resistance to any Parliamentary control over the colonial judiciaries.

\section{The ENGLish Background}

Before discussing the controversies over judicial tenure in the colonies it is useful to trace briefly the course of judicial tenure in England, although at times colonial attitudes indicated an ignorance of some of the specifics of earlier developments. ${ }^{6}$ From the time of Edward I (1272-1307) until the reign of Charles I (1625-1649), the judges of King's Bench and Common Bench or Common Pleas held office during pleasure, quam diu nobis placuerit, ${ }^{7}$ almost without exception. ${ }^{8}$ The Chief Justice of King's Bench was usually appointed by a writ or mandate containing no clause as to tenure, but we have seen no suggestion that he served otherwise than during pleasure when so appointed. ${ }^{9}$ Before the reign of Henry VI (1422-1461), the

lution-The Triumphant Empire: Britain SaILS into the Storm, 1770-1776, at 13845 (1965); 3 T. Hutchinson, History of the Colony and Province of MassachuSETTS-BAY FROM 1749 TO 1774, at 259-65, 277-80, 296-97, 317-26 (L.S. Mayo ed. 1936) [hereinafter cited as Hutchinson, Hist. Massachusetts-BAy].

512 \& 13 Will. 3, c. $2, \S 3$ (1701). The statute provided, upon accession of the House of Hanover, tenure during good behavior for the judges of the common law courts at Westminster.

${ }^{6}$ Certainly no colonial had access to the patent rolls and other English records.

${ }^{7}$ The alternate phrase, durante bene placito, which occurs in the American debates, does not appear in the earlier enrolled commissions. It may stem from Lord Coke, E. Coke, The Fourth Part of the Institutes of the Laws of England: Concerning THE JuRISDiction OF THE Courts 75 (1st publ. 1644) [hereinafter cited as Coke, FouRTh INSTITUTE], or from use by the later Stuarts.

${ }^{8}$ This statement is based upon an extended examination of the printed Calendar of Patent Rolls, the printed Letrers and Papers of Henry VIII, and the patents enrolled on Chancery rolls, C 66 series, at the Public Record Office, London. It is supported by C.H. McIlwain, The Tenure of English Judges, in Constitutionalism and the Changing World 294, 296-97 (1939) (the general statements are based "on an examination of practically all the surviving patents for high judicial office between the thirteenth century and the seventeenth") [hereinafter cited as McIlwais]; CokE, Fourth Institure, supra note 7, at 74-75, 99; J. Fortescue, DE LAudibus Legum Angliae, ch. 51 (1672). See G. Rose, Observations on the Historical Work of the Late Right Honorable Charles James Fox 35 (1809) [hereinafter cited as Rose, Observatrons]; see also S. Heywood, Historical Account of the Tenure by which the Judges Held their Offices Under the House of Stuart, in A Vindication of Mr. Fox's History of the Early Part of the Reign of James the Second app. I, III (1811) [hereinafter cited as HeYwoon, Historical Account].

9 This statement is based upon the examination of a substantial number of writs or 
Barons of the Court of Exchequer also held office during pleasure. Henry VI, however, began the practice of appointing the barons during good behavior. With a few exceptions around 1470 , this shift to tenure for good behavior seemingly continued until $1628,{ }^{10}$ when the reluctance of Chief Baron Walter to quit his office resulted in the issuance of subsequent commissions to the barons during pleasure. ${ }^{11}$ Significantly, the original purpose of tenure during good behavior was to protect the patent holders against arbitrary removal from office and loss of emoluments, rather than to assure impartiality in the administration of justice. ${ }^{12}$

Although the removal of judges without cause was not of major significance in the constitutional struggle between Charles I and Parliament, ${ }^{13}$ in January, $1640 / 41$ a Parliamentary address presented to the King requested that future judicial appointments be during good behavior, quam diu se bene gesserint. ${ }^{14}$ In

mandates to the Chief Justices of King's Bench found in the Chancery rolls, C 66 series (Public Record Office, London).

11 This statement is based on McIlwain, supra note 8 , at 297-98, and a selective examination of the Chancery rolls, C 66 series (Public Record Office, London).

${ }^{11}$ Mcllwain, supra note 8, at 298. Charles I attempted to remove Sir John Walter, but Walter refused to surrender his patent and continued in office until death, although upon royal command he declined to sit in court. Heywood, Historical Account, supra note 8, at IV. The patent of his successor, Sir Humphrey Davenport, was during pleasure, and the patents of the other barons (James Weston, Richard Weston, and Edward Hendon) were afterwards conformable to his. PRO:C 66 series (Public Record Office, London). Rose, Observations, supra note 8 , at 35 , notes that the barons held on good behavior "till the appointment of Sir Humphrey Davenport, 6th Charles which was quam diu nobis placuerit; and the patents of the other Barons were afterwards conformable thereto."

${ }^{12}$ See the lament about the 1626 removal of Chief Justice Crewe in $2 \mathrm{~J}$. RushwORTH, Historical COLlections 1358 (1680) [hereinafter cited as Rushworth]. For a general discussion of tenure of office under Charles I, see G. AyLmER, THE King's Servants, The Givil Service of Charles I, 1625-1642, at 106-25 (1961). For "life tenure" as opposed to tenure during good behavior, see R. BERGER, IMPEACHMENT: The Constitutional Problems 125-35 (1973).

${ }^{13}$ Chief Justice Crewe was removed from King's Bench in November, 1626 for refusing to subscribe a paper recognizing the legality of the collection of forced loans. 6 S.R. Gardiner, History of ENgland 149 (1909); 6 E. Foss, Judges of ENGLand 291 (1857). See also 2 Rushworth, supra note 12, at 1358, app. 266-67. In September, 1634 Chief Justice Robert Heath of Common Pleas was dismissed from office without any reasons assigned. Memoir of Chief Justice Heath 21, in 1 Bibliographical AND Historical Miscellanies (Philobiblon Soc. Pub. 1854). It is probable that the King was of the opinion that Heath did not incline to the royal view on the question of shipmoney. 7 S.R. Gardiner, History of ENGLANd 361-62 (1909); 6 E. Foss, Judges of ENGLAND 322-23 (1857); 2 RUSHWORTH, supra note 12, at app. 253.

142 Rushworth, supra note 12, at 1366; 2 PARL. Hist. Eng. 702 (1641). The movement appears to have originated in the House of Lords. On January 11, 1640/41 a committee of this House was appointed to consider, among other things, judges holding 
July, 1641 , in a speech to both Houses giving assent to several bills, the King decreed that judges should thereafter hold their offices during good behavior. ${ }^{15}$ This promise was observed in later appointments, ${ }^{16}$ but tenure during good behavior was alluded to constantly in later documents of the constitutional crisis. ${ }^{17}$

On October 30, 1648 Parliament passed an ordinance appointing several judicial officers, including Chief Justices of King's Bench and Common Pleas and the Chief Baron of the Exchequer. All the commissions were to be issued quam diu se bene gesserint. ${ }^{18}$ Apparently during the following years of the Interregnum judicial tenure was during good behavior. ${ }^{19}$

places durante bene placito. 4 H.L. JouR. 129 (1641). On January 12 certain members were deputed to attend Charles and pray that the justices of King's Bench and Common Pleas and the Barons of the Exchequer might hold their places quam diu se bene gesserint. This desire was reported granted on January 15. Id. 130-32.

152 Rushworth, supra note 12, at 1366; 9 S.R. Gardiner, History of ENGland 263 (1909).

${ }^{16}$ McIlwain, supra note 8, at 300; 20 T. Rymer, Foedera 517 (1717); Heywood, Historical Account, supra note 8, at V-VI. There were King's Bench appointments during good behavior, starting January 23, 1640/41, to Robert Heath, Thomas Malet, Robert Heath (Chief Justice), Francis Bacon, and Henry Rolle. John Banks was appointed Chief Justice of Common Bench during good behavior on January 29, 1640/41. In 1645 Edward Atkyns and Richard Tomlyns were appointed to the Court of Exchequer during good behavior. These patents are all enrolled in PRO:C 66 series (Public Record Office, London).

${ }^{17}$ In the Grand Remonstrance presented to the King in December, 1641, it was complained that judges had been put out of office for refusing to act against their oaths and consciences, that others had been so awed that they dared not do their duties, and that for better judicial control the quam diu se bene gesserit clause was omitted from the patents and a new durante bene placito clause inserted. Constitutional Documents of the Puritan Revolution 1625-1660, at 213 (S.R. Gardiner ed. 1906). See also J. Forster, The Debates on the Grand Remonstrance 234 (1860). Later in the Nineteen Propositions sent by Parliament to the King in June, 1642 it was proposed that all judges hold their places during good behavior. Constirutional Documents of THE Puritan Revolution, supra, at 253. Likewise, in the propositions presented to the King at the Treaty of Oxford in February, 1642/43 the judicial appointees advanced by Parliament and all judges of the three central courts in the future were to hold their places quam diu se bene gesserint by letters patent under the Great Seal. Id. 265. In the Parliamentary propositions discussed at Uxbridge in early 1645 it was proposed that the judges of King's Bench and Common Pleas, the Barons of the Exchequer, and the Chancellor, along with other dignitaries, be nominated by both Houses at their next sitting. Id. 284. The propositions sent to the King at Newcastle in July, 1646 contained a similar clause. Id. 304. For the noncommittal reply to the $17 \mathrm{th}$ Article in the third answer of the King to the Newcastle propositions, see id. 315.

${ }^{18} 1$ ACTS AND ORdinances of THE INTERREGNum, 1642-1660, at 1226 (C. Firth \& R. Rait eds. 1911).

19 F.A. INDERwick, The INTERregnum 170,180 (1891). Compare the statement in Heywood, Historical Account, supra note 8, at VI, that during the Protectorate of Oliver Cromwell "either the patents of the Barons of the Exchequer and of the other courts must have been made out durante bene placito only, or he disregarded them al- 
Upon the Restoration the earlier commissions issued by Charles II (1660-1685) contained the quam diu se bene gesserit clause. ${ }^{20}$ But beginning with 1668 virtually all appointments were again made during pleasure. ${ }^{21}$ During the reign of Charles II at least eleven, and probably fourteen, persons were removed from judicial office for political reasons. ${ }^{22}$ One case from this period, the attempt in late 1672 to remove Justice John Archer from the Court of Common Pleas, for reasons not evident from the memorandum accounts, illustrates both the value and disadvantage of commissions during good behavior. Because Archer held office during good behavior, he refused to surrender his patent without a scire facias. But none was brought, and Archer continued to enjoy the profits of Common Pleas according to his patent, although he was prohibited from sitting judicially and another judge was sworn in his place. ${ }^{23}$ Thus at the cost of an

together, for he removed a Baron of the Exchequer [Thorpe] and a Judge of the Court of Upper Bench [Richard Newdigate]." See also McIlwain, supra note 8, at 300.

${ }^{20}$ The patent rolls, C 66 series (Public Record Office, London), show appointments to King's Bench during good behavior to Malet (Mallett), Wyndham, Kelyng, and Morton. The several appointments of Chief Justices (Foster, Hyde, Kelyng) contained no clause as to tenure. In Common Pleas commissions to Foster, Hyde, Tyrrell, Bridgeman, Browne, and Archer were all during good behavior. In the Court of Exchequer patents to Bridgeman, Atkyns, Turnor, Hale, and Rainesford were all quam diu se bene gesserint. See also McIlwain, supra note 8 , at 300.

21 The patent rolls, C 66 series (Public Record Office, London), reveal twelve patents to judges of King's Bench containing quam diu nobis placuerit or durante bene placito clauses. Several of the latter were to Chief Justices. The May 18, 1671 writ appointing Matthew Hale Chief Justice contained no provision as to tenure. Fourteen appointments to Common Pleas found were during pleasure; the durante bene placito language was used only once. Twelve appointments to the Court of Exchequer found were quam diu nobis placuerit. For the patent to Sir Richard Rainesford as puisne justice of King's Bench in February, 1668/69 see the memorandum report in 1 Sid. 408, 82 Eng. Rep. 1185 (K.B. 1669). In a 1670 cause, Dighton's Case, 1 Ventris 82, 86 Eng. Rep. 57 (K.B. 1670 ), the "offices of judicature in the Courts at Westminster" were mentioned by King's Bench to be held only durante bene placito. 2 R. GNEIST, History of THE ENGLish Constiturion 300 (1886) states that "[a]fter 1665 Charles II appears to have made use of the long prorogation of Parliament, quietly to reintroduce revocable appointments durante bene placito."

227 E. Foss, Judges of England 4 (1857). See Heywood, Historical Account, supra note 8 , at XVI-XIX, for particulars as to the removed personnel. The best account of these removals appears in Havighurst, The Judiciary and Politics in the Reign of Charles II, 66 L.Q.R. 62, 229 (1950). See also Corson, Judges and Statutory Tenure in England in the Seventeenth Century, 42 JuRID. REv. 136 (1930) [hereinafter cited as Corson]; 6 W.S. Holdsworth, A History OF ENGLish LAw 500-18 (1924).

${ }^{2 \overline{3}}$ Г. Raymond, 217, 83 Eng. Rep. 113 (K.B. 1673); T. Jones, 43, 84 Eng. Rep. 1138 (K.B. 1676); lengthy memorandum dating after April, 1723 on precedence of judges, in Fortescue 382, 394, 92 Eng. Rep. 907. See 2 Rushworth, supra note 12, at 1366. See also the argument of Levinz in Harcourt v. Fox, 1 Show. K.B. 506, 510, 89 Eng. Rep. $720,721-22$ (1693). 
extra salary the Crown was able to obtain a judge more to its liking, notwithstanding the tenure clause. There is some evidence of legislative desire to curb this manipulation of the judiciary. In 1673/74 a bill providing that judges should hold their places during good behavior was debated in the House of Commons but failed to become law. ${ }^{24}$ In 1680 a resolution to the same effect was passed. ${ }^{25}$

During the reign of James II (1685-1688), with judges holding office during pleasure, dismissal from office for political reasons continued unrestrainedly. Twelve judges at Westminster Hall were removed from office. ${ }^{26}$ As James' reign came to an end several speakers, in debates preliminary to a declaration of rights, insisted upon judicial commissions during good behavior. ${ }^{27}$ But the hastily drawn Bill of Rights of 1689 included no such provision. ${ }^{28}$ After the accession of William and Mary (1689-1702), however, the commissions to the judges at Westminster were granted during good behavior. ${ }^{29}$ The Crown vetoed a 1691/92 bill making such tenure compulsory on the ground that the salaries provided therein were charged to the hereditary revenue without the previous sanction of the Crown. ${ }^{30}$ It remained, therefore, for the Act of Settlement of

${ }^{24}$ In February, 1673/74 a bill ascertaining the powers and fees in the patents of judges was read twice and referred to a committee. 9 H.C. Jour. 305,309 (1674).

${ }^{25}$ On December 16, 1680 it was resolved in Committee of the Whole House that the House be moved to bring in a bill providing that judges might hold their places and salaries quam diu se bene gesserint. Id. 682. The House inserted a provision limiting the bill to judges thereafter appointed. Id. 683. See also M.A. Thomson, A ConstrtUtional History of ENGLAND, 1642-1801, at 142 (1938).

${ }^{26}$ Havighurst, James II and the Twelve Men in Scarlet, 69 L.Q.R. 522 (1953). See also 7 E. Foss, Judges of ENGLANd passim (1857); Heywood, Historical Account, supra note 8, at XIX-XXIII; G.W. Keeton, Lord Chancellor Jeffreys and the Stuart Cause 94-115 (1965). Thirty-two patents found enrolled (PRO:C 66 series, Public Record Office, London) contained the quam diu nobis placuerit clause; the October 23, 1685 writ to Edward Herbert as Chief Justice of King's Bench did not refer to tenure. The appointment of Robert Wright as Chief Justice of King's Bench on April 21, 1687 was durante bene placito.

273 H. Hallam, The Constitutional History of England 262 (1872) [hereinafter cited as HaLLAM].

${ }^{28} 1$ W. \& M., sess. 2, c. 2 (1689). See also Corson, supra note 22, at 145-46.

${ }^{29}$ The thirty-one patents found enrolled (PRO:C 66 series, Public Record Office, London) are all quam diu se bene gesserint. For mention of Chief Justice Holt's commission see 2 Ld. Raymond 769, 92 Eng. Rep. 13 (K.B. 1702); for the decision by Justice Turton of King's Bench and Baron Hatsell of the Exchequer "against their own interest" in 1702 that "a patent to be Judge quam diu se bene gesserint, $\sigma^{\circ} c$. determined by the demise of the King," but which "many doubted," see id. at 768; for the statements of Powis, Levinz, and Chief Justice Holt see Harcourt v. Fox, 1 Show. K.B. 428, 512, 535, 89 Eng. Rep. 681-82, 720-23, 734 (1693).

${ }^{30}$ Historical Manuscripts Commission, Fourteenth Rep. app. 6, 76, No. 565, 
$1701^{31}$ to secure the independence of the judiciary. The act provided that upon the accession of the House of Hanover judicial commissions were to be issued quam diu se bene gesserint and judicial salaries ascertained and established, but upon address of both Houses of Parliament it might be lawful to remove judges. During the reign of Anne (1702-1714) all commissions continued to be granted during good behavior, ${ }^{32}$ although the Act itself did not take effect until her death.

One last detail remained before judicial tenure during good behavior could be a complete working reality. Until this time, all commissions became vacant upon demise of the King. An early act of Anne, however, provided that they should continue for an additional six months; another statute, in 1707, extended this policy to the offices in the plantations. ${ }^{33}$ Finally, an enactment in the first year of the reign of George III (1760-1820) announced that judges were to continue in office during good behavior, notwithstanding the demise of the King or of any of his heirs or successors. ${ }^{34}$

\section{A. Precedents for the Colonies}

What does this somewhat confused background tell us about the precedent to be applied in the case of judicial tenure in the colonies? Under orthodox reception theories most colonists were not entitled to the benefits of the Act of Settlement, a post-conquest or post-settlement act which by its terms did

xix (1895). See also 4 T. Macaulay, History of England from the Accession of James The SeCOND, 292-93 (Cambridge ed. 1901). For the course of the bill in the House of Commons, see 10 H.C. Jour. 574, 583, 646, 655, 661, 678, 685, 693-94 (1692).

${ }^{31} 12 \& 13$ Will. 3, c. $2, \S 3$ (1701). It was originally resolved that the judges should be removable upon the address of either House of Parliament. 13 H.C. Jour. 401, 525 (1701). See Rubioni, The Precarious Independence of the Judiciary, 1688-1701, 83 L.Q.R. 343-45 (1967).

${ }^{32}$ The eighteen appointments during Anne's reign found on the patent rolls, C 66 series (Public Record Office, London), are all quam diu se bene gesserint. See also 2 Ld. Raymond 768-69, 92 Eng. Rep. 13-14 (K.B. 1702).

${ }^{33} 1$ Anne, st. 1 , c. 8 (1702); 6 Anne, c. 7 (1707).

${ }^{34} 1$ Geo. 3, c. 23 (1761). The King introduced the subject in a March 3, 1761 speech to both Houses. In this speech the King stated: "I look upon the independency and uprightness of the Judges of the land as essential to the impartial administration of justice, as one of the best securities to the rights and liberties of my loving subjects, and as most conducive to the honour of the crown." 15 Parl. Hisr. ENG. 1007 (1761). The resolution of the Commons respecting the matter is at id. 1013. See also $1 \mathrm{~J}$. Adolphus, History of England 20 (1802); 1 H. Walpole, Memoirs of the Reign of King George the ThIRD 41 (G. Barker ed. 1894). 
not extend to the American plantations. ${ }^{35}$ Arguably, any commissions during good behavior granted in the mother country prior to the Act of Settlement were void or else merely granted office during pleasure, because ancient office had to be granted in such form and manner as formerly unless such manner had been altered by Parliament. ${ }^{36}$ Since originally tenure was during pleasure and Parliament had made no change, the commissions prior to accession of the House of Hanover formed no part of the common law of England that the colonists could claim either by birthright or by virtue of their right under colonial patents. ${ }^{37}$

On the other hand, Barons of the Exchequer had been appointed during good behavior since the fifteenth century, ${ }^{38}$ and some colonists regarded this as clear precedent for tenure during good behavior. In some colonies acts of assembly or ordinances endowed Superior Court judges with the privileges of the judges of King's Bench, Common Bench or Common Pleas, and Exchequer. John Adams, among others, questioned whether the tenure of the Barons of the Exchequer should control in the case of the Superior Court judges. ${ }^{39}$

This uncertainty regarding the substance of the received common law may help to explain the tendency on the part of some colonists to base claims to tenure during good behavior on natural law. ${ }^{40}$

\section{B. Instructions to Royal Governors}

Commissions to governors in the royal colonies were silent

${ }^{35}$ For a discussion of reception theories see J. Smith, The English Criminal Law in America, in The English Legal System: Carryover to the Colonies 3-60 (Seminar series, Clark Library, University of California, Los Angeles 1975).

${ }^{36}$ The principle is stated in CoKE, FouRTH INSTITUTE, supra note 7, at 75, 87; Harcourt v. Fox, 1 Show. K.B., 506, 535, 89 Eng. Rep. 720, 734 (1693). The Parliamentary ordinance, of course, had no validity in altering established custom.

373 WoRKs of John Adams 550-51, 563-64 (C.F. Adams ed. 1856) [hereinafter cited as ADAMS Works].

${ }^{38}$ See text accompanying note 10 supra.

${ }^{39}$ This question was raised by John Adams in connection with the court establishment in Massachusetts. 3 ADAMs Works, supra note 37, at 525. But cf. the March, 1766 commission during pleasure of Governor Tryon of North Carolina to Robert Howe as

- Chief Baron of the Exchequer. North Carolina Commission Book 1761-1773, at 38-39 (Ms. North Carolina Department of Archives and History, Raleigh).

40 John Adams wrote that, "there are respectable lawyers who maintain that the judges here hold their offices during good behavior; but it is upon other principles, not upon the common law of England." 3 AdaMs Works, supra note 37, at 522. See also id. 533. 
on the gubernatorial power to remove judges from office. It was apparently understood, however, that the removal power was possessed by implication, because at an early period the Crown issued instructions to control the circumstances of such removal. A 1670 instruction to the Governor of Jamaica prohibited his displacing any judicial appointees "without good and sufficient cause for so doing." 41 Similar instructions to other colonies in the years following required the cause of removal to be reported to the English authorities. ${ }^{42}$ No evidence indicates that the several councils were to participate in removing judges, despite their participation in making appointments. ${ }^{43}$ In 1674 , to prevent arbitrary removal of judges and justices of the peace, the Crown instructed the Governors of Jamaica and Barbados not to express any time limitation in the commissions of such appointees. ${ }^{44}$ Although its corrective force is difficult to discern, this instruction was regularly included in instructions issued thereafter and was not questioned until $1754 .{ }^{45}$ Later royal instructions of 1754 and 1761 and the occasions for their issuance are discussed below. ${ }^{46}$ Although the evidence is fragmentary, it appears that by 1700 judges in the royal colonies were commissioned uniformly during pleasure by the Governor on his own initiative or upon warrant from the Crown. Judicial salaries were usually provided on an annual basis by the several assemblies, thus giving popular elements some control over the judiciary.

\section{Judicial Tenure in the Colonies}

\section{A. Pennsyluania}

The first important colonial controversy over judicial tenure arose in Pennsylvania a few years after the passage of the Act of Settlement. Some evidence shows that in the early period of this proprietary colony judicial commissions were issued during good

41 Royal INstructions to British Colonial Governors, 1670-1776 \$519 (L.W. Labaree 1935, reprinted 1967) [hereinafter cited as Royal Instructions]. An August, 1671 relation of the state of the island noted that the judges of the Court of Common Pleas and of the Supreme Court were commissioned during pleasure. 1 Journal of THE ASSEMBLy OF JAMAiCA app. 36-37 (1811).

421 ROYAL InSTRUCTIONs, supra note 41 , at $\$ 516$.

${ }^{43} I d . \S 512$.

${ }^{44} I d$.

${ }^{45} \mathrm{Id}$. Governor Popple of Bermuda questioned how failure to express any limitation of time in judicial commissions prevented arbitrary removal. 2 id. 866.

${ }^{46}$ See text accompanying notes 72-77 infra. 
behavior, but by the early eighteenth century tenure had become at pleasure. ${ }^{47}$ In 1704/05 Queen Anne in Council disallowed a 1701 act establishing a new judicial system in the province. A great debate over the substance of a new act ensued, pitting Lieutenant Governor John Evans and his Council, representing the Proprietaries, against the Assembly, led by speaker David Lloyd, with judicial tenure one of the matters at issue. ${ }^{48}$

The Assembly conceded the Lieutenant Governor's power of appointment, but insisted that judges be displaced for misbehavior at the request of the Assembly. ${ }^{49}$ The Assembly based its proposal upon a draft by Roger Mompesson ${ }^{50}$ prepared after the enactment of the Act of Settlement for insertion in a bill for establishment of courts in the province. ${ }^{51}$ Lieutenant Governor Evans replied that he would not grant the powers of appointment and removal because these powers had been vested in the Governor by practice since the beginning of the province and were possessed by the governors of the other American dominions of the Queen. ${ }^{52}$ Referring to the Act of Settlement, he added that not every act of Parliament should be copied immediately in the colony, because the conditions favoring passage in England might not exist in Pennsylvania. ${ }^{53} \mathrm{He}$ urged that relatively fewer men were qualified for judicial office in the colonies than in England, and that allowing the Governor to replace inferior judges with superior ones at every available opportunity was necessary to improve the judiciary. Speaker Lloyd insisted that tenure during good behavior was a right of the subjects

${ }^{47}$ In the 1682 Frame of Government, judges, masters of the rolls, and justices of the peace were to be appointed during good behavior. Charter to WILLIAM PENN AND Laws of the Province of Pennsylvania Passed Between the Years 1682 and 1700 , at 97 (George, Nead, \& McCamont eds. 1879) [hereinafter cited as CharTER AND LAws Prov. PA.]. The 1684 commissions to Provincial Court judges were to be of two years duration, "you and every of you behaving yourselves well therein, and acting according to the same." 1 Minutes of the Provincial Council of Pennsylvania 121 (1852) [hereinafter cited as Mins. Prov. Coun. PA.]

${ }^{48}$ See Smith, Administrative Control of the Courts of the American Plantations, 61 Colum. L. Rev. 1210, 1217-20 (1961); see generally R. LOKkEN, David Lloyd, Colonial Lawmaker 166-76 (1959); W. Shepherd, History of Proprietary Government in Pennsylvania 379-80 (1896) [hereinafter cited as Shepherd, Hist. Prop. Gov. Pa.].

492 Mins. Prov. Coun. PA., supra note 47, at 267-68.

so British barrister, Chief Justice of the Supreme Court of New York, and, in 1703, judge of the Pennsylvania Vice-Admiralty Court.

512 Mins. Prov. Coun. PA., supra note 47, at 294.

52 Id. 273, 288. In the later debates Evans doubted whether the Frame of Government with its provision as to good behavior was in force in the province. Id. 312 .

${ }^{53}$ Id. 302. See also id. 310-11. 
even without an act of Parliament. ${ }^{54}$ Evans accused the Assembly of most unjustly perverting both the words and sense of the Parliamentary precedent. ${ }^{\mathbf{5 5}}$

The Lieutenant Governor further protested the inequity of depriving the Governor of the power to remove an appointee without "a Process at Law" while at the same time granting to the Assembly the power of removal "without any trial or Conviction." 56 Governors, answerable principally to the imperial authorities, would be "extremely deficient in their power" if they could not remove a judge "whose malefeasance might give the ministry occasion to Command him to be so removed ...."57 In an effort to reach a settlement, Evans declared that, if the Assembly would provide an adequate salary for a qualified person as Chief Justice, he would grant this appointee tenure during good behavior and would make it lawful for the Assembly to remove him by address as in England. ${ }^{58}$ The attempted compromise failed. Evans bitterly accused the Assembly of seeking to combine the power of removal with control over judicial salaries in order to achieve domination of the Supreme Court and turn it against the Proprietaries-all as part of a scheme to "reverse the method of Government according to [the] English Constitution, and Establish one more nearly resembling a republick in its stead $" 59$

\section{B. New York}

The broadside literature of complaint that circulated in New York in the early 1730's raised the issue of judicial tenure only in a random manner. ${ }^{60}$ The issue was squarely raised, however, in

${ }^{54}$ Id. 312-13. Lloyd claimed that tenure by good behavior had formerly been the custom in England, that it had been changed during Stuart times, and that the Act of Settlement had only restored a right of the people.

${ }^{55}$ Id. 324.

${ }^{56}$ Id. 302-03, 313, 324. Evans denied that he would not agree that a judge should be displaced upon proof made by the Assembly of his official misbehavior.

${ }^{57} I d .325$.

${ }^{58}$ Id. 324. See also id. 303.

${ }^{59}$ Id. 325.

${ }^{60}$ The anonymous author of To F[RANCIS] H[ARRISON], EsQ. (1732) wrote that if he were a legislator, he would insist on a law or laws rendering the judges' commissions during life and ascertaining their salaries. Robert Dissolution (pseud.), in his A LetTer from a Gentleman in the Country to his Friend in Town (1732), wanted "[t]he Judges by their Commissions to be independent of the Governour, as well as the People, that they mayn't be tempted by Fear or Favour, to stretch the Laws to the Hurt of any Man." 
two famous causes of the decade-King $v$ Van Dam ${ }^{61}$ and King $\%$. Zenger. ${ }^{62}$ Chief Justice Lewis Morris' partisan attitude, which eventually caused Governor William Cosby to terminate his commission during pleasure, and the complexities associated with the equity jurisdiction of the Supreme Court sitting as a court of exchequer, created peculiar problems in these trials. ${ }^{63}$ After Morris had stalked out of the arguments in Van Dam and Judge James DeLancey had disqualified himself, Judge Frederick Philipse continued to hear arguments on a demurrer interposed by Van Dam's counsel, James Alexander and William Smith. In April, 1733 an exception was taken to Philipse's continuing to hear the cause on the ground that the Supreme Court judges should be commissioned quam diu se bene gesserint rather than quam diu nobis placuerit. Although the exception was overruled, ${ }^{64}$ the judicial tenure issue was kept alive by Zenger's New-York Weekly Journal. ${ }^{65}$

In April, 1735, in Zenger, defense counsel Alexander and Smith offered several exceptions to the power of then Chief Justice DeLancey and Judge Philipse to hear the cause. One exception to the commissions of both judges was that the authority of a judge of King's Bench in England, by which cognizance was claimed, was granted only during pleasure, whereas under the applicable statute (presumably the Act of Settlement) it should have been granted during good behavior. ${ }^{66}$ Smith then asked to be heard on two questions: (1) whether the subject had a right to take exceptions regarding the legality of the judges' commissions and (2) whether the exceptions to the commissions were valid.

${ }^{61}$ For a discussion of this case see Smith \& Hershkowitz, Courts of Equity in the Province of New York: The Cosby Controzersy, 1732-1736, 16 AM. J. Legal Hist. 1, 16-31 (1972) [hereinafter cited as Smith \& Hershkowitz].

62 See J. Alexander, A Brief Narrative of the Case and Trial of John Peter Zenger, Printer of the New-York Weekly Journal (S. Katz ed. 1963) [hereinafter cited as Alexander, Brief Narrative]. The information brought against Zenger was for falsely, seditiously, and scandalously publishing certain libels against the Governor and other officials of the province. In the libel appearing April 18, 1734 in the NewYork Weekly Journal, a summarization of the major grievances against the Cosby administration included "judges arbitrarily displaced." AleXANder, Brief Narrative, supra, at 136.

${ }^{63}$ Smith \& Hershkowitz, supra note 61 , at 16-31.

${ }^{64}$ Id. 31 .

${ }^{65}$ The New-York Weekly Journal, Feb. 25, 1733/34, at 3-4; id., Mar. 18, 1733/34, at 4; id., Apr. 1, 1734, at 2-3; id., Apr. 29, 1734, at 2-3. See also the reference to the arbitrary dismissal of judges in the suggestion that Cosby be impeached. Id., Apr. 18, 1734 , at 2.

${ }^{66}$ Alexander, Brief Narrative, supra note 62 , at 50-53. 
The Chief Justice thereupon declared that he would neither hear nor allow the exceptions, and answered Smith as follows:

[Y]ou thought to have gained a great deal of applause and popularity by opposing this Court, as you did the Court of Exchequer; but you have brought it to that point that either we must go from the bench or you from the bar: Therefore we exclude you and Mr. Alexander from the bar. ${ }^{67}$

An order was entered accordingly and at first John Chambers, assigned by the court, and then Andrew Hamilton, an experienced trial lawyer of the Philadelphia bar, took over the defense. Zenger pleaded not guilty and was acquitted by the jury. ${ }^{68} \mathrm{Smith}$ and Alexander were not restored to practice until the October 1737 term of the Supreme Court. ${ }^{69}$

Lewis Morris left New York in November, 1734 accompanied by his son, Robert Hunter Morris, and spent a futile eighteen months in London seeking vindication (achieved in part) and reinstatement to judicial office by the Privy Council (never achieved).$^{70}$ In his printed case presented to the Committee of the Privy Council and heard in November, 1735, Morris,

${ }^{67}$ Id. 53; 2 Rutherfurd Collection 8, 24, 94-95 (Ms. New-York Historical Society, New York City). For comments on the silencing of Smith and Alexander by Cadwallader Colden (April 23, 1735) and Lewis Morris (Aug. 9, 1735, Oct. 24, 1735, and Jan. $11,1735 / 36)$ see 2 id. 118, 126, 170. For Alexander's appraisal expressed to Morris, see 2 id. 142. See also the manuscript headed "To be inquired by the Committee upon the Administration of Justice [New York Assembly] whether Chief Justice DeLancey has not misbehaved himself in his office four ways." 2 id. 199-200.

${ }^{68}$ See Alexander, Brief Narrative, supra note 62, at 20-22; Smith \& Hershkowitz, supra note 61, at 40-41. James Alexander, in his trial strategy proposals to Hamilton, suggested reference to arbitrary displacement of judges by Cosby and other governors. 2 Rutherfurd Collection 41 (Ms. New-York Historical Society, New York City).

${ }^{69}$ Smith \& Hershkowitz, supra note 61 , at 48 .

${ }^{70}$ The Morris mission is discussed at length in S. Katz, NewCastle's NEw York: Anglo-American Politics, 1732-1753, at 91-132 (1968) [hereinafter cited as Katz, NewCASTLE's New YoRK]. A London diary kept by Robert Hunter Morris (Apr. 17, 1735 to Jan. 4, 1736) is printed in McAnear, An American in London, 1735-1736, 64 PA. Mag. Hist. AND BIoG. 164, 356 (1940). Lewis Morris, Jr.'s proposed instructions to his father included: "Ninthly. To get the Judges whenever appointed to be quam diu se bene gesseritt." William Smith in his proposed instructions urged "[t]hat something be proposed for determining the qualification of Judges and the securing to them the enjoyment of these offices during good behavior." Alexander commented, "This is included in the Law for regulating courts of judicature." 2 Rutherfurd Collection 71-72 (Ms. New-York Historical Society, New York City). A draft of instructions by Alexander included as objectives the restoration of Lewis Morris to office quam diu se bene gesserit and instructions to the Governor to assent to an act establishing courts of judicature and the forms of commission for judges thereof. 2 id. 74. See also Smith \& Hershkowitz, supra note 61 , at 28-31. 
in the course of answering some twenty-six charges made by Governor Cosby, pointed out the dangers to the property and liberties of the subjects created by arbitrary removal of judges. Morris hoped that the gubernatorial power of removal in the colonies would be restricted in the future and made to conform to the laws of England as strictly as the circumstances of distant dominions would permit. He urged, as necessary to the independence of the judiciary, a royal declaration that judges would not be removable at the pleasure of a governor but only at the pleasure of the Grown. ${ }^{71}$ We suspect this plea fell upon deaf ears.

This episode in New York is unique in that it involved, among other things, the only specific removal from judicial office by Crown or proprietor that is complained of in the entire controversy over judicial tenure in the American colonies. There was no counterpart in the plantations of the wholesale dismissals from judicial office that characterized the reigns of Charles II and James II in England. And despite the furor over independence of the judiciary precious little evidence exists that the popularly elected assemblies ever were amenable to making the judges independent of "the people" by permanent grants of adequate salaries.

\section{New Instructions}

The struggle with the English administrators for tenure during good behavior began on the island of Jamaica. As early as 1722, as one phase of the struggle for the benefit of the laws of England, it was proposed that judges of the Supreme Court should hold office quam diu se bene gesserint, but should be removable upon address of the Assembly. ${ }^{72}$ But it was not until November, 1751 that an act was passed in Jamaica providing that no Chief Justice or Judge of the Supreme Court of Judicature should be removed or suspended without cause except by

${ }^{71}$ The Case of Lewis Morris, EsQ.; Late Chief Justice of the Privince of New-York, Who was Removed fRom the SAID OfFice by His EXCEllency William Cosby, Eso.; Governor of the SAID Province (London 1735). Copies may be found in the New Jersey Historical Society, Newark, and in 2 Rutherfurd Collection 76 (Ms. New-York Historical Society, New York City). The New-York Historical Society has recently acquired what appears to be the corrected manuscript copy of the case (with the last page missing) as sent to the printer.

722 Journals of the Assembly of Jamaica, 427. For background see A. Whitson, The Constitutional Development of Jamaica chs. I, VII (1929) and J. Smith, Appeals to the Privy Council from the American Plantations 476-80 (1950). 
royal command signified through the usual channels. The act permitted removal by the Governor with the advice and consent of his council only after showing sufficient cause and giving twenty-one days' notice in writing, culminating in an open trial, hearing, and examination of the evidence on both sides. ${ }^{73}$ Crown law officers Dudley Ryder and William Murray, in a June, 1753 report, concluded that the act directly affected the royal prerogative and that no justification of gubernatorial abuse of authority had been offered. Even if a justification had been offered, reform by royal authority seemed more appropriate to the Crown law officers than reform by legislative interposition. Furthermore, in the opinions of Ryder and Murray, it did not appear from the circumstances in Jamaica, or in any other plantation, that it would be advisable for either colonial or British interests that colonial judges hold their places quam diu se bene gesserint. ${ }^{74}$ Thereupon, the act was disallowed by the King in Council in February, $1754 .^{75}$

With the problem of judicial tenure thus in focus, the Board of Trade, in making recommendations in June, 1754 with respect to instructions for Governor Arthur Dobbs of North Carolina, advised omission of the prevalent ambiguous restraint upon arbitrary removals from judicial office. In its place a clause was inserted providing that all commissions to judges, justices of the peace, and other necessary officers should be granted during pleasure only. ${ }^{76}$ This provision was then gradually inserted in instructions to other colonies. ${ }^{77}$

${ }^{73}$ The act was entitled "An Act providing that all the Judges of the Supreme Court of Judicature of this island shall hold their Offices, Quam diu se bene gesserint." 4 Laws of Jamaica 67-68 (Ms. Jamaica Record Office, Jamaica). In the preamble the existence of such tenure in England was recited, as was the royal direction that proceedings in Jamaica should be as identical as possible to those in England. The channels enumerated were the sign manual, Order in Council, order of a principal secretary of state, and order of the Board of Trade. For the legislative career of the bill, see 4 Journais of the Assembly of Jamaica, 302, 306, 310-13.

744 Acts of the Privy Council of England, Colonial Series, 1613-1783 § 216 (W. Grant \& J. Munro eds. 1911) [hereinafter cited as APC, CoL.]; Colonial Office Papers, CO 137/25/June 22, 1753 (no pagination) (Public Record Office, London); 2 G. Chalmers, Opinions of Eminent Lawyers on Various Points of ENglish JurisPRUDENCE 105 (1814).

${ }^{75} 4$ APC, Col., supra note 74 , at $\$ 216$. Tenure durante bene placito, however, remained a source of grievance in the colony. Witness the characterization of this tenure as "slippery and uncertain." The Privileges of the Island of Jamaica Vindicated 49 (1766).

${ }^{76} 5$ The Colonial Records of North Carolina 1104, 1124 (W. Saunders ed. 1887) [hereinafter cited as CoL. REC. N.C.].

${ }_{77} 1$ ROYAL INSTRUCTIONS, supra note 41 , at $\$ 513$. 


\section{Pennsylvania Revisited}

The issue of judicial tenure did not vanish in Pennsylvania. In 1743 Thomas Penn, on behalf of the proprietors, wrote from England to Governor Thomas that it would be unwise to make any statement in Council concerning judges holding office during good behavior. The proprietors would never agree to alter the commissions of the judges, wrote Penn, unless the Supreme Court was put on the footing it held in England by depriving the judges of seats in the Assembly and changing the method of choosing sheriffs. ${ }^{78}$ In 1753 the proprietors expressed a willingness to commission judges during good behavior, provided the Assembly settled a fund to pay the judges proper salaries. ${ }^{\mathbf{7 9}}$

A February 22, 1757 report or representation of a Committee of Grievances of the Assembly that was designed for use by commissioners sent to England to solicit redress of many violations of the constitution gave prominence to the judicial tenure problem. ${ }^{80}$ This report asserted that it was the import and design of the charter that judges should hold their commissions in a manner agreeable to the laws and customs of Englandan understanding confirmed by the original Frame of Government-and that the governors of the province for many years had granted all judges of the Supreme Court and of the Courts of Common Pleas commissions to be held during their will and pleasure in contravention of the charter. The result of subjecting the judges to the influence of the proprietaries and their governors, favorites, and creatures was that

[T] he Laws may not be duly administered or executed, but often wrested from their true Sense, to serve particular Purposes; the Foundation of Justice may be liable to be destroyed, and the Lives, Laws, Liberties, Privileges and Properties of the People thereby rendered precarious, and altogether insecure, to the great Disgrace of our Laws, and the inconceivable injury of his Majesty's Subjects. ${ }^{81}$

${ }^{78}$ Letter from Thomas Penn to Gov. 'Thomas, Aug. 21, 1743, in 2 Penn Letter Books 46 (Ms. Historical Society of Pennsylvania, Philadelphia) [hereinafter cited as Penn Letter Books].

${ }^{79}$ See ShePherd, Hist. Prop. Gov. PA., supra note 48, at 398-99.

${ }^{80}$ See 6 Pennsylvania Archives 4537, 4540 (8th ser.) [hereinafter cited as Pa. Arch.]; 7 The Papers of Benjamin Frankin 136, 140-41 (L. Labaree et al. eds., 19 vols. to date, 1959-) [hereinafter cited as Papers of Benjamin FrankLin].

${ }^{81} 6$ PA. ARCH., supra note 80, at 4540; 7 PAPERs of Benjamin Franklin, supra note 80 , at 140 . 
Agitation for tenure during good behavior was one aspect of a cluster of anti-proprietary activities managed by Joseph Galloway. His 1759 pamphlet, $A$ True and Impartial State of the Province of Pennsylvania, demanded, among other things, judicial tenure during good behavior. ${ }^{82}$ When, in September, 1759, the Assembly rejected at the third reading a bill designed to remedy sundry defects in a 1722 act establishing courts, it ordered a committee headed by Galloway to bring a new bill rendering independent the judges of the Supreme Court and Court of Common Pleas by requiring issuance of their commissions quam diu se bene gesserint ${ }^{83}$ The bill accordingly brought in was enacted into law on September 29, 1759, the assent of Lieutenant Governor William Denny having been obtained by a "judicious bribe." 84 This act provided for five judges of a Court of Common Pleas in each county. These judges, together with those of the Supreme Court, were to hold office quam diu se bene gesserint. Removal by the executive was possible upon address of the Assembly. Salaries for both categories of judges were fixed by the act. ${ }^{85}$

The proprietors quickly petitioned the Crown against confirmation of the act, alleging a serious encroachment upon governmental powers granted by the charter. ${ }^{86}$ When the act came before the Board of Trade in the legislative review process, the provision for judicial tenure during good behavior was singled out for censure in a June, 1760 representation. The Board cited the treatment of the 1751 Jamaican act as precedent for disallowance. The case for disallowance of the Pennsylvania act appeared even stronger to the Board because the charter conferred upon the proprietors the power of judicial nomination

${ }^{82}$ As to authorship see 1 Pamphlets of the American Revolution 1750-1776, at 700 (B. Bailyn ed. 1965).

${ }^{83} 6$ PA. ARCH., supra note 80, at 5034-35, 5038-39.

${ }^{84}$ The term "judicious bribe" appears in W. Root, The Relations of Pennsylvania with the British Government, 1696-1765, at 176 (1912). Shepherd refers to the "venality" of Denny. HIST. Prop. Gov. PA., supra note 48, at 399.

856 PA. ARCH., supra note 80, at 5040, 5043-45. At a September 26 meeting of the Governor and Council, all the latter with one exception opposed the bill. The only amendment proposed by the Governor was on an unimportant point. 8 Miss. Prov. Coun. PA., supra note 47, at 399-402. For the act entitled "A Supplement to the Act, Entitled 'An Act for Establishing Courts of Judicature in This Province'" see 5 Statutes at Large of Penssylvania from 1682 to 1801 , at $462-65$ J. Mitchell \& H. Flanders eds. 1898) [hereinafter cited as Stat. at Large Pa.].

${ }_{86} 5$ Stat. at LARge Pa., supra note 85, at 661-63, 689. Argument on the act was heard by the Board of Trade on June 3, 1760.Id. 696-97. 
without limitation and because no incidents of judicial maladministration had been alleged. Finally, the Board thought that adoption of tenure during good behavior would insure office to those of inferior ability who might otherwise be removed as the colony became richer and more populous. ${ }^{87}$ In a September 2, 1760 Order in Council the Lord Privy Seal was directed to prepare and pass under the privy seal a proper instrument for declaring the act void. ${ }^{88}$

Following passage of the 1759 law Denny had issued commissions during good behavior to justices of the Court of Common Pleas in at least three counties under province seal and in the name of King George II. ${ }^{89}$ When notified of the disallowance, at a date after the demise of George II, Lieutenant Governor James Hamilton, successor to Denny, issued writs of supersedeas to vacate these patents and commissioned other persons to hold office under the 1722 act at the will and pleasure of the proprietors. The earlier patentees refused to recognize the writs on the ground that their commissions were not based on the 1759 act but were good at common law and could not be vacated except for misbehavior in office. ${ }^{90}$ Hamilton took the position that the commissions were issued under the 1759 act and were invalidated by the disallowance. Even if the patents were good at common law, Denny maintained, they were terminated nonetheless by the demise of George II. ${ }^{91}$ If 6 Anne c. $7^{92}$ were applicable, the Governor, by the express terms of the statute, still had a right to remove by supersedeas during the six month extension.

Seeking clarification, the proprietors requested the opinion of Attorney General Charles Pratt on the following questions: (1) whether the patents granted after passage of the 1759 law were vacated by its disallowance; (2) whether the Governor was restrained from commissioning judges during good behavior by the province's ancient practice of granting commissions during pleasure; (3) whether the patents ceased and determined at the

${ }^{87} \bar{I} d .697,722-\overline{2} 4$.

${ }^{88}$ Id. 653-59.

${ }^{89}$ The case later submitted to Attorney General Charles Pratt only mentions commissions to the judges of the Court of Common Pleas in Philadelphia. 6 id. 566-71. Cf. 8 Mins. Prov. Coun. Pa., supra note 47, at 562, 573, 575, mentioning in addition the Courts of Common Pleas in Lancaster and Chester counties.

${ }^{90} 6$ Stat. at LaRge PA., supra 85 , at 568.

${ }^{91}$ Id. 568-69.

${ }^{92}$ See text accompanying note 32 supra. 
King's death; and, if not, whether the Governor had nonetheless legally removed the judges under 6 Anne c.7. ${ }^{93}$

In June, 1761 Pratt replied that: (1) assuming the patents were issued under the 1759 act, they became void ipso facto upon disallowance of the act; (2) if the patents were granted before passage of the act they would be good, despite the Governor's breach of proprietary instructions; and (3) it was difficult to comprehend how the judges could be commissioned in the King's name since they were not the King's judges and their tenure was not dependent on the King's life. ${ }^{94}$ Even if they were regarded as the King's judges, Pratt was not satisfied that the commissions determined upon the demise of the crown.

While the 1759 act was being disallowed in Whitehall, the issue of judicial tenure was being kept alive in the province by publication in 1760 of another pamphlet, believed to have been penned by Galloway, entitled $A$ Letter to the People of Pennsylvania; Occasioned by the Assembly's Passing that Important Act, for Constituting the Judges of the Supream Courts and Common-Pleas, During Good Behaviour. ${ }^{95}$ Reviewing the experiences in England and Pennsylvania, the pamphlet insisted in strident tones that judicial tenure during good behavior was the ancient and indubitable right of the inhabitants of Pennsylvania: "Tis yours by the usage and custom of ages; 'tis yours by the rules of reason; 'tis yours by covenant with the first founder of your government; 'tis yours by the united consent of Kings, Lords, and Commons; 'tis yours by birthright and as Englishmen."96 The pamphlet warned the reader that "if an impartial and independent administration of justice is once wrested from your hands, neither the money in your pockets, nor the clothes on your backs, nor your inheritances, nor even your persons can remain long safe from violation."97

Despite the disallowance of the 1759 act and the opinion of the Attorney General, judicial tenure remained a live political issue in Pennsylvania. On March 24, 1764, when the Assembly passed twenty-six "Resolves upon the Present Circumstances" in-

${ }^{93} 6$ Stat. at Large PA., supra note 85 , at 569-70.

${ }^{94}$ Id. at 570-71.

95 The pamphlet is printed in 1 Pamphlets of THE American Revolution 1750-1776, at 256-72 (B. Bailyn ed. 1965).

${ }^{96} \mathrm{Id}$. at $271-72$.

${ }^{\mathbf{s 7}} I d .272$ (footnote omitted). 
corporating the grievances of the inhabitants, the fifteenth resolution was

That the Proprietaries contending for the Power of Appointing Judges during their pleasure, who are to determine in all Causes between the Proprietaries and their Tenants, the Inhabitants of the Province, is unjust, renders the Liberties and Properties of the Subject precarious, and dependent on the Proprietary Will and Pleasure, and is by no Colour of Reason supportable. ${ }^{98}$

In his "Explanatory Remarks on the Assembly's Resolves" Benjamin Franklin emphasized the even greater need for tenure during good behavior in the province than in England, because the proprietors, unlike the English Kings, had great property interests. ${ }^{99}$ When Franklin drafted a petition of the freeholders and inhabitants requesting the King to assume governance of the province, he touched on the judicial tenure issue, ${ }^{100}$ as he similarly did in a preface to a publication of Galloway's speech in the Assembly answering John Dickinson's speech on the petition to the King. ${ }^{101}$ William Smith responded to Franklin's remarks on behalf of the proprietary interests. ${ }^{102}$ In 1765 the proprietors declared that if the Assembly would get a recommendation from the Crown that judges in the province be appointed during good behavior, they would agree to appoint them in that way. ${ }^{103}$ In view of what was happening in other colonies this seems to have been an idle gesture. When a circuit bill was under consideration in 1767, Franklin urged Galloway to have the Assembly balance

987 PA. ARch., supra note 80, at 5591-95; 11 PAPERs of Benjamin Franklin, supra note 80 , at 130 . See the Sept. 24, 1764 letter from Chief Justice William Allen expressing great resentment at the implication that the judges had ever shown or even had occassion to show partiality to the proprietors in cases before them. THE BURD Papers. Extracts from Chief Justice William Allen's Letter Book 57 (L. Walker ed. 1897). See also Franklin's letter of Sept. 25, 1764 to Richard Jackson on Allen's reaction. 11 Papers of Benjamin Franklin, supra note 80, at 357-58. For Allen's independence in writs of assistance cases, see Dickerson, Writs of Assistance as a Cause of the Revolution in The Era of the American Revolution 40, 58-61 (R.B. Morris ed. 1939).

9911 Papers of Benjamin Franklin, supra note 80, at 134, 140-41; Pennsylvania Gazette, Mar. 29, 1764, at 2, col. 3.

100 II PAPERS OF Benjamin FrankLin, supra note 80, at 145, 147.

${ }^{101}$ Id. $267,301$.

${ }^{102}$ Id. 486, 512-14.

${ }^{103}$ Letters from Thomas Penn to William Allen and John Penn, July 13, 1765, in 8 Penn Letter Books, supra note 78, at 271, 275. 
the interest of the proprietors with that of the judges by providing adequate salaries. ${ }^{104}$

In early December, 1767 John Dickinson, a Pennsylvania lawyer and politician, began publication of his famous series of twelve "Letters" by "A Farmer in Pennsylvania" in two Philadelphia newspapers, The Pennsylvania Chronicle, and Universal Advertiser and The Pennsylvania Gazette. ${ }^{105}$ These "Letters" were also published serially in other colonial newspapers and in pamphlet form. Although it emphasized non-importation of British manufactures, Letter IX also stressed the necessity for the appointment of judges during good behavior in the American colonies. ${ }^{106}$ Dickinson saw a particular need for an independent judiciary in America both to protect the subjects against the arbitrary use of the writs of assistance provided by the Townshend Revenue Act and to guard them from the arbitrary advancement of the royal prerogative that might result from the confused state of the reception of English law in the American plantations. ${ }^{107}$ The letter also alerted the reader that any Assembly control of the judiciary through the voting of salaries was undermined by the declared intention of the Townshend Revenue Act ${ }^{108}$ "that a revenue should be raised in His Majesty's dominions in America, for making a more certain and adequate provision for defraying the charge of the administration of justice, and the support of civil government" in such provinces where it should be found necessary. ${ }^{109}$

${ }^{104} 14$ Papers of Benjamin Franklin, supra note 80 , at $1 \overline{2} 2$. See also Franklin's remarks to Professor Gottfried Achenwall at the University of Göttingen in July, 1766. 13 id. 361.

${ }^{105}$ See 11 L. Gipson, The British Empire Before the American Revolution -The Triumphant Empire: The Rumbling of the Coming Storm, 1766-1770, at 146-49 (1965). The letters have been reprinted recently in EMPIRE AND NATION 1-85 (F. McDonald ed. 1962).

${ }^{106}$ EMPIRE ANd Nation 50-58 (F. McDonald ed. 1962).

${ }^{107}$ Id. 53-55 (quoting, on the issues of reception, 1 W. SMITH, THE History OF THE Province of New-York 259-60 (M. Kammen ed. 1972)).

1087 Geo. 3, c. 46, \& 1 (1767).

${ }^{109}$ Empire AND NATION 56-58 (F. McDonald ed. 1962). See also the Boston Evening-Post of May 23, 1768, printing a portion of an address by Dickinson, given in Philadelphia on April 28, in which he attacked the Act for making judges independent of the people. Starting with the issue of Feb. 6, 1769, a series of ten letters appeared in the Evening-Post, some signed "N.P.," in answer to Letters from a Farmer. In letters VI (continued in the issue of Apr. 10) and IX (May 29) Dickinson's views on the independence of the judiciary were assailed, largely on the ground of his continuing to have the judges dependent upon the assemblies for salaries. The writer demanded to know what difference it should make to the colonists what faces appeared on the bench "as long as 
In early January, 1768 Franklin published his famous "Causes of the American Discontents Before 1768."110 $\mathrm{He}$ stressed, among other things, that payment of salaries from revenues raised by the Townshend Act to judges commissioned by the Crown during pleasure could place all the weight of interest or influence on one side. He argued that if the Crown appointed able and honest judges during good behavior, the assemblies should settle permanent and ample salaries on them. At present the assemblies had no means of getting rid of ignorant or unjust judges except by starving them out of office. ${ }^{111}$ In September, 1768 the Committee of Correspondence of the Assembly wrote to Franklin and Richard Jackson emphasizing the danger of paying salaries from the revenues raised by Parliament to judges holding commissions during the pleasure of the proprietors. ${ }^{112}$

\section{E. New Jersey}

In the royal province of New Jersey judicial commissions had been granted uniformly during pleasure until 1739. In 1739 Governor Lewis Morris, with the unanimous advice of his Council and perhaps with his own experience in mind, appointed his son, Robert Hunter Morris, Chief Justice of the Supreme Court during good behavior. Ten years later Governor Jonathan Belcher was prevailed upon to give like commissions to Samuel Nevill and Charles Reade, the second and third justices of the Supreme Court. Later, without advice from his Council, Belcher commissioned some of the county judges during good behavior. ${ }^{113}$ If these appointments came to the notice of the Board of Trade, they evoked no comments.

they [the Assembly] have it in their power to starve them into a compliance with their most romantic designs?"

${ }^{110} 15$ Papers of Benjamin Franklin, supra note 80, at 3. Franklin's tract was first published in The London Chronicle, Jan. 5-7, 1768.

1115 Papers of Benjamin Franklin, supra note 80, at 9.

${ }^{112} I d$. 210-14. An incorrect report that the judges in Ireland had been granted tenure during good behavior intensified feelings in the colonies. For further comment on the Townshend Revenue Act and judicial salaries see $16 \mathrm{id} .54-55,243-49 ; 17 \mathrm{id} .33$, 35 (The Colonists' Advocate V, printed in the Public Advertiser, Jan. 25, 1770); 18 id. $149-50$.

${ }^{113}$ Kemmerer, Judges' Good Behavior Tenure in Colonial New Jersey, in 56 New JERSEY Historical Society Procendings 18, 19 (1938) [hereinafter cited as Judges' Tenure]; Letter from Board of Trade to King, June 17, 1760, in 9 Documents Relating to the Colonial History of the State of New Jersey 231 (F. Ricord \& W. Nelson eds. 1885) [hereinafter cited as Doc. ReL. Col. HIST. N.J.]. See Nadelhaft, Politics and the Judicial Tenure Fight in Colonial New Jersej, 28 WM. \& MARY Q. 46 (1971) for the view that the controversy in New Jersey was political and did not involve constitutional prin- 
In 1754 the younger Morris, about to be appointed Lieutenant Governor of proprietary Pennsylvania, tendered his resignation and proposed for political purposes that Richard Saltar, a prominent lawyer and East New Jersey proprietor, succeed him as Chief Justice. ${ }^{114}$ Seeking to disparage Nevill (a popular leader, probably not too sympathetic to the East New Jersey proprietary claims) and abandoning ideological consistency, Morris wrote to the Board of Trade criticizing Belcher's appointments of judges during good behavior. Morris questioned whether such commissions would stand the test of a legal inquiry and proposed that future gubernatorial instructions prohibit the granting of offices during life. Because most offices of profit in New York and New Jersey were held during life, one Governor, by filling all offices with his own creatures, might leave his successor without power or influence and render him unable to carry on the affairs of the Crown. Morris acknowledged that the judges of the Supreme Court, where all matters of consequence were tried, should be in some measure independent of the Governor, who might have personal interests at stake. But, he argued, the self interest of the Governors was no reason for allowing the judges to be independent of the Crown. Such judges could be commissioned pursuant to mandamus from England, subject to suspension by the Governor and Council but removable only by the Crown. ${ }^{115}$

The Board of 'Trade failed to acknowledge Morris' resignation as Chief Justice, and Belcher failed to appoint Saltar to that office. Morris continued to sit as Chief Justice during several terms in 1756 and 1757 after he had relinquished the Pennsylvania post. ${ }^{116}$ In early 1757 the Board of Trade, regarding Morris' previous resignation as valid, recommended one William Aynsley, later scornfully characterized as treasurer to a turnpike in northern England, ${ }^{117}$ as Chief Justice of New Jersey. Morris

ciples. Kemmerer also touches on the judicial tenure dispute in his Path to FreEdom: The Struggle for Self-Government in Colonial. New Jersey, 1703-1776, at 154-55, 267-73 (1940).

${ }^{114}$ Judges' Tenure, supra note 113 , at 20, 21 n.10.

${ }^{115}$ Id. 21 n.10, citing 4 J. Smith Mss. 170 (Ms. Library Company of Philadelphia, Philadelphia).

${ }^{116}$ Letters from Francis Bernard to Board of Trade, Mar. 22, 1760, and from Board of Trade to King, June 17, 1760, in 9 Doc. REL. Col. Hist. N.J., supra note 113, at 213-14, 231. 1972).

1172 W. Smith, The History of the Province of New-York 249 (M. Kammen ed. 
apparently made no attempt to oppose the appointment during a prolonged stay in England. ${ }^{118}$ Aynsley died, however, a short time after his arrival in New Jersey in $1758 .{ }^{119}$ Whether the Assembly, which felt that Morris had been turned out of office to make room for the English appointee, would have voted Aynsley a salary is problematical. ${ }^{120}$ In 1758 Belcher's successor, Francis Bernard, appraised for the Board of Trade the comparative merits of Nevill, Saltar, and Reade as potential Chief Justices. Bernard characterized Morris as being unwilling to take a new commission unless the tenure was during good behavior, which was not permissible. ${ }^{121}$ Morris returned to New Jersey in the summer of 1759 and informed Bernard that he intended to resume his position as Chief Justice by virtue of his former patent which, he said, had not been surrendered or otherwise determined. The Governor persuaded Morris to wait until the Board of Trade could be consulted by agreeing to make no other appointment in the meantime. ${ }^{122}$ Shortly thereafter word arrived that the authorities in Whitehall had authorized the appointment of a London attorney, Nathaniel Jones, to the post. ${ }^{123}$

Jones arrived in New Jersey in November, 1759. Informed of Morris' claim, he refused to assume office until the dispute was settled. Morris, perhaps counting on Assembly support, refused to yield to Governor Bernard's pressure, which included a threat to make public Morris' earlier letter on judicial tenure. ${ }^{124}$ The dispute between Morris and Jones came before the Su-

${ }^{118}$ Letter from Board of Trade to King, June 17, 1760, in 9 Doc. REL. Col. HIST. N.J., supra note 113 , at $232 ; 4$ APC, Col., supra note 74 , at $\S 258 ; 2$ W. SMITH, ThE History of THE Province of New-York 249 (M. Kammen ed. 1972).

119 Letters from Francis Bernard to Board of Trade, July 7, 1758, and from Board of Trade to King, June 17, 1760, in 9 Doc. REL. Col. Hist. N.J., supra note 113, at 124, 232.

${ }^{120}$ Judges' Tenure, supra note 113, at 22, citing 1 Bernard Papers 144, 196 (J. Sparks Collection, Houghton Library, Harvard University).

${ }^{121}$ Judges' Tenure, supra note 113 , at 22-23, citing 1 Bernard Papers, 160, 180-83 (J. Sparks Collection, Houghton Library, Harvard University).

${ }^{122}$ Letter from Francis Bernard to Board of Trade, Aug. 28, 1759, in 9 Doc. Rez. CoL. Hrst. N.J., supra note 113, at 176-77.

${ }^{123}$ Letters from Board of Trade to King, May 22, 1759, and from Francis Bernard to Board of Trade, Aug. 28, 1759, in id. 173, 177. William Smith later described him as a Newgate solicitor who left his wife in the arms of an adulterer. 2 W. SMITH, ThE History of THE Province of NEW-YoRK 249 (M. Kammen ed. 1972).

${ }^{124}$ Letters from Board of Trade to Francis Bernard, Dec. 14, 1759, and from Francis Bernard to Board of Trade, Feb. 25, 1760, in 9 Doc. ReL. Col. Hist. N.J., supra note 113, at 191-92, 210-11; Judges' Tenure, supra note 113, at 23-24, citing 1 Bernard Papers 181-83, 186-88, 208 (J. Sparks Collection, Houghton Library, Harvard University). See also text accompanying notes $114-15$ supra. 
preme Court when Jones sought to have the oath of office administered and to be admitted to the office of Chief Justice. In the subsequent proceeding, from which Morris disqualified himself, the court upheld Morris' right to the office. Judge Nevill ruled that Morris had a freehold in the office and that "nothing was shown legally to divest him" of it. ${ }^{125}$ The court refused to administer the oath to Jones or to admit him to office, leaving his right to the office to be determined by due course of law. ${ }^{126}$ Bernard immediately wrote to the Board of Trade suggesting that the court's order be brought before the Governor and Council by writ of error. He protested that the dispute was more than a mere contest for an office, characterizing it instead as a commencement of hostilities against the government. He suggested that his successor, Thomas Boone, who was expected to arrive in New Jersey at any moment, be instructed not to recognize Morris as Chief Justice. ${ }^{127}$ After considering Bernard's report, the Board of Trade referred the matter to the Attorney General to decide what should be done to uphold the Crown's "Right of Nomination against the extraordinary and unprecedented Claim" of Morris. ${ }^{128}$

Following Boone's arrival, Morris represented in vain that popular demand made him insist on a commission during good behavior. Some attempts to have Morris offered the position of Chief Justice of New York proved unsuccessful, but by a narrow margin Boone persuaded the New Jersey Assembly to vote the usual salary of $£ 100$ to whichever Chief Justice the Crown decided was entitled to the office. ${ }^{129}$ In late 1760 , however, Jones, disillusioned and in want, returned to England. The news of the death of George II reached New Jersey in early 1761, but Boone took no steps to issue new commissions. ${ }^{130}$

Boone's successor, Josiah Hardy, good natured and far from

1259 Doc. Rel. Col. Hist. N.J., supra note 113, at 217.

${ }^{126}$ A copy of the Supreme Court minutes is at id. 214-18.

${ }^{127}$ Letter from Francis Bernard to Board of Trade, Mar. 22, 1760, in id. 213; see Judges' Tenure, supra note 113, at 25, citing 1 Bernard Papers 197, 198, 241 (J. Sparks Collection, Houghton Library, Harvard University).

${ }^{128}$ Letter from Board of Trade to King, June 17, 1760, in 9 Doc. REL. Col. Hist. N.J., supra note 113 , at 233.

${ }^{129}$ Letters from R.H. Morris to Gov. Boone, Aug. 10, 1760, and from Gov. Boone to Board of Trade, Dec. 15, 1760, in id. 235-38 (Morris' version of the dispute), 248; Judges' Tenure, supra note 113, at 25, citing 1 Bernard Papers, 267 (J. Sparks Collection, Houghton Library, Harvard University).

130 9 Doc. ReL. Col. Hist. N.J., supra note 113, at 342-43; Judges' Tenure, supra note 113 , at 26 . 
astute, arrived in the province in October, 1761, alerted en route by Lieutenant Governor Cadwallader Colden of New York to the dispute over judicial tenure raging in New York and New Jersey. On November 30, 1761 the Assembly met and, according to a later report by Hardy, resolved not to make any provisions in the bill for support of the government for judges who accepted commissions during pleasure. ${ }^{131}$ Acting upon the unanimous advice of his Council, Hardy renewed the commissions to Morris, Nevill, and Saltar during good behavior. ${ }^{132}$ What pressures the Assembly or the judges exerted on Hardy is a matter of conjecture. The Governor justified his actions by declaring that he feared bad consequences and sought only to appease the people, who appeared dissatisfied. ${ }^{133}$ On the same day that Hardy signed the three commissions the Board of Trade in England, prompted by events in New York, ${ }^{134}$ drafted circular instructions to all royal Governors warning them not to assent to any bill providing that judges should hold office during good behavior "upon pain of being removed from your government."135

Hardy's letter and one from Colden in New York, indicating capitulation to the Assembly's wishes in the matter of judicial tenure in that province, arrived at the Board of Trade on the same date, March 18, 1762. The Board immediately sought the opinion of the Crown law officers whether the New Jersey appointments, contrary to the Board's instructions, were legal and valid, and if not, by what authority and in what manner they might be set aside. ${ }^{136}$ The Board, believing that nothing could extenuate "so premeditated and unprecedented an act of dis-

${ }^{131}$ Judges' Tenure, supra note 113, at 26; 9 Colden Letrers and Papers 162 (1937); Letter from Gov. Hardy to Board of Trade, Jan. 20, 1762, in 9 Doc. ReL. Col. Hist. N.J., supra note 113 , at 346-47.

13217 Doc. ReL. CoL. Hrst. N.J., supra note 113, at 269.

${ }^{133}$ Letter from Gov. Hardy to Board of Trade, Jan. 20, 1762, in 9 id. 346-47. For a Jerseyite equating good behavior tenure with "Revolution Principles," see the item in the New-York Mercury, Dec. 21, 1761, reprinted in 20 Archives of the State of New JERSEY 652 (W. Nelson ed. 1898).

${ }^{134}$ See text accompanying notes 143-79 infra.

1351 Royal Instructions, supra note 41 , at $\$$ 514; 9 Doc. Rel. Col. Hist. N.J., supra note 113, at 308-15; 4 APC. CoL., supra note 74 , at $\S 460$.

${ }^{136}$ Journal of the Commissioners for Trade and Plantations . . Preserved in the Public Record Office, 1759-1763, at 263, 265 (1935) [hereinafter cited as JCTP]; 9 Doc. Rec. Col. Hist. N.J., supra note 113, at 349-51. For the January 18, 1763 opinion of Attorney General Charles Yorke that the appointments were illegal and invalid, see 9 id. $380-81$. 
obedience,"137 was anxious to prevent the New Jersey action from having dire consequences in Pennsylvania and New York. Without waiting for the opinion of the Crown law officers, the Board advised, in a strongly worded report, that Hardy be recalled as a necessary example to deter others in the same situation from similar acts of disobedience to royal orders. ${ }^{138}$

When Hardy finally received the Board's instruction, he successfully exerted pressure on the three judges to surrender their commissions during good behavior. ${ }^{139}$ Exactly when the Governor's June, 1762 notification of the surrenders reached the Board is not certain. In any event, Hardy was recalled by a letter of September 11, 1762, and replaced by William Franklin. ${ }^{140}$ Deeply shocked at the severity of the Board's action, Hardy could not comprehend the objections to his conduct; not having seen the Board's representation, he had no opportunity to offer any justification. ${ }^{141}$ His protestations failed to mollify the imperial authorities, however, and he never received another appointment as Governor. By early 1764 Morris, Nevill, and Saltar were all dead. Reade served shortly as Chief Justice, but in October, 1764 the Crown appointed Frederick Smyth as Chief Justice during pleasure. Smyth served until the Revolution. ${ }^{\mathbf{1 4 2}}$

\section{F. New York: The Second Round}

Contemporaneously with events in Pennsylvania and New Jersey judicial tenure was again receiving attention in $\mathrm{New}$ York. In this colony, despite his instructions, Governor George Clinton had found it necessary or advisable during his administration to grant commissions during good behavior to Chief Justice DeLancey, and puisne justices Frederick Philipse, John Chambers (appointed when Philipse died) and Daniel Horsmanden. While acting as Lieutenant Governor, DeLancey also had commissioned under the same tenure David Jones as

${ }^{137}$ Letter from Board of Trade to King, Mar. 27, 1762, in 9 Doc. ReL. Col. Hist. N.J., supra note 113 , at 361 .

${ }^{138}$ Id. 361-62.

${ }^{139}$ Letters from Gov. Hardy to Sec'y Pownall, June 22, 1762, and to Board of Trade, July 16,1762 , in id. $364,367$.

140 Letter from Earl of Egremont to Gov. Hardy, Sept. 11, 1762, in id. 374-75. The draft of a commission for Franklin was ordered on August 20, 1762 and submitted on August 25. Id. 368-72.

${ }_{141}$ Letter from Gov. Hardy to Earl of Egremont, Dec. 3, 1762, in id. 379-80.

${ }^{142}$ Judges' Tenure, supra note 113 , at $29 \mathrm{n} .64$. For evidence that the issue lingered on in New Jersey see the complaint in "J. W." AN AdDress to THE FreEholders of New-Jersey, on the Subject of Public Salaries 17 (1763). 
the fourth justice. ${ }^{143}$ Thus when Cadwallader Colden assumed the government upon DeLancey's death in July, 1760 the Supreme Court consisted of Chambers, Horsmanden, and Jones -all commissioned during good behavior. William Smith, Sr. applied to Colden for appointment to the vacant post of Chief Justice, but Colden refused to grant it except during pleasure. ${ }^{144}$ Colden explained his refusal by pointing to the trouble caused during Clinton's administration by the tenure of De-

${ }^{143}$ Letter from Lt. Gov. Cadwallader Colden to Board of Trade, Aug. 21, 1761, in 7 Documents Relating to the Colonial. History of the State of New York 468 (E. O'Callaghan \& B. Fernow eds. 1856-1887) [hereinafter cited as Doc. ReL. CoL. Hist. N.Y.]. On Sept. 13, 1744 Clinton told the Council that he had been informed that the Chief Justice of New Jersey had a commission during good behavior and that he thought it proper that the New York Chief Justice be commissioned similarly. Horsmanden, the third judge, moved that the other judges likewise have such commissions. The Council advised a commission during good behavior for Chief Justice DeLancey but delayed decision on the motion on behalf of the puisne judges. 19 Minutes of the Governor and Council of the Province of New York 282 (reverse pagination) (Ms. New York State Library, Albany) [hereinafter cited as N.Y. Council Mins.]. Nothing was done in the matter, and Horsmanden was removed from office later in 1747 without cause and without the advice and consent of the Council. Shortly before the close of his administration in 1753. Governor Clinton, having broken with Delancey, restored Horsmanden to office with a commission during good behavior. 4 New York 22-23, in Chalmers Collection (Ms. New York Public Library, New York City). The Crown law officers, in a July 25, 1753 report, were of the opinion that Clinton should not have commissioned DeLancey during good behavior, but since the power of appointment given was general, the grant was good in point of law and could not be revoked absent misbehavior. 2 G. Chalmers, Opinions of Eminent Lawyers on Various Points of English Jurisprudence 177-78 (1814). On the relations of Clinton and DeLancey, in general, see KaTZ, NewCASTLE'S New YoRK, supra note 70, at 164-93, 233-42.

Wiliam Smith Jr. gives some account of the shifting patterns of politics that influenced appointments to the bench in New York. According to Smith, during the time that Governor Clinton's disputes with the Assembly were running high and his growing weariness with Colden had led him to rely on James Alexander, the Second Judge of the Supreme Court Frederick Philipse died. Chambers, then well disposed toward Clinton, was the favored choice for appointment to the vacancy. Since he foresaw, however, that Clinton would not remain in command much longer Chambers feared that, if he accepted the office during pleasure, he would be removed by a future Governor under DeLancey's influence. Therefore, he absolutely declined the office unless it were granted upon the best tenure. Clinton then ventured to grant it, despite his instructions. $4 \mathrm{Wm}$. Smith Papers, sub Nov. 24, 1761 (Ms. New York Public Library, New York City).

${ }^{144}$ Colden promised to recommend Smith to the ministry and assured him that he would not grant the office to any of the puisne judges because they were unfit for the office. $4 \mathrm{Wm}$. Smith Papers, sub Nov. 24, 1761 (Ms. New York Public Library, New York City). See also The Conduct of Cadwallader Colden . . . Relating to the Judges Commissions, Appeals to the King, and the Stamp-Duty (1767) in 2 COLDEN LETTER Books 434 (1878) [hereinafter cited as Conduct of Colden]. For some discussion of the judicial tenure controversy from varying standpoints, see A. Keys, Cadwallader Colden 268-95 (1906); D. Dillon, The New York Triumvirate 57-65 (1949); M. Klein, Prelude to Revolution in New York: Jury Trials and Judicial Tenure, in The Politics of Diversity: Essays in the History of Colonial New York 154, 157-66 (1974). 
Lancey's commission. ${ }^{145}$ Colonial proponents desired a speedy appointment during good behavior to avoid an unfit appointee from England. ${ }^{146}$ The Assembly prepared an address demanding an appointment during good behavior but agreed to withdraw it after being assured that the matter would be presented to the ministry. Colden thereupon suggested to Whitehall an appointment during pleasure coupled with a direction to the Governor to assent to an act providing that no judge should be removed or suspended by the Governor without express royal command, Assembly address, or the advice and consent of at least seven councillors. ${ }^{147}$

In the meantime William Smith, Richard Hunter Morris, Chambers and Horsmanden (the puisne justices), and Robert R. Livingston (the leader of the Assembly) were contending for appointment to the vacancy. When these competitors found

1454 WM. Smith Papers, sub Nov. 24, 1761 (New York Public Library, New York City). For an account of the trouble see Letter from Gov. Clinton to the Board of Trade, June 22, 1747, in 6 Doc. Rel. Col. Hisr. N.Y., supra note 143, at 356-57, 792.

${ }_{146}$ This is vividly shown in the rough draft of an undated letter by Robert Hunter

Morris to an unidentified New York addressee:

The office of Chief Justice of your province being vacant by the suddain death of the late Lt. Gov. nothing can be more interesting to the province than to have it properly filled, at least as well filled as the circumstances of the country will admit. It is an office of great importance, the lives, libertys and properties of the inhabitants are in great measure in the hand of such an officer and if it be left vacant till notice for it gets to England, there is too much reason to fear that a wretch like Ainsley or Jones or some necessitous dependent of a great man, some tool worn out in the trade of corruption and no longer able to serve the mean purpose of his employers will be sent to preside in your highest court and vested with a jurisdiction not only over the lives and property of the people but over all the subordinate courts and officers of justice and holding his place (which probably will be his only means of living) at the will and pleasure of his superiors will be a ready tool to carry the arbitrary measures of a weak or wicked governor into execution. You may indeed be better off and a man of understanding and virtue may be your portion but when you consider the general cast of the people sent from England to fill the highest as well as other offices in America, and the number of dependants that the present system of corruption throws into the train of every man in power, I do not think you have any reason to expect a great proportion of virtue and understanding will fall to your share upon the present occasion. It seems to me therefore absolutely necessary if you mean to avoid the danger that will probably attend an English appointment that the office should immediately be filled by the President and to render the appointment permanent and secure as well as to induce a gentleman of honor and fortune to accept of it, I should think the tenure of it should be during good behavior. This is constitutional in England and ought much more to be so in America "as his Majesty can delegate his powers but not his virtue." Morris (Robert) Papers (Ms. Rutgers University Library).

${ }^{147}$ Conduct of Colden, supra note 144, at 434-35. 
Colden, who was congenitally hostile to the New York legal profession, disinclined to appoint any of their number, a spirit of enmity developed. As a result, following an alleged vacation of all commissions by the death of George II in October, 1760, the disgruntled parties insisted upon new judicial commissions during good behavior as in England. Colden's refusal to accede to this demand prepared the way for an attempt to retain the advantages conferred by such commissions through legislative action. ${ }^{148}$ In March, 1761 a bill entitled "An Act to remove Doubts and Scruples, occasioned by the Demise of the King" was introduced in the Assembly. ${ }^{149}$ One objective of the bill was to require judicial commissions during good behavior, with a proviso allowing removal by the Governor or commander-in-chief upon Assembly address or by advice of at least seven council members. Colden thought that removal also should be at the royal pleasure, signified under signet and sign manual, to protect the royal prerogative as well as guard against arbitrary gubernatorial action. He prevailed upon the Assembly, however, to postpone consideration of the bill for the time being, arguing persuasively that more pressing matters required the legislature's attention. ${ }^{150}$

In May, 1761, another act providing that Supreme Court judges should hold their commissions during good behavior passed both legislative bodies. Colden, however, refused to assent to this bill. ${ }^{151}$ The incumbent judges thereupon petitioned

${ }^{148} 4 \mathrm{Wm}$. Smith Papers, sub Nov. 24, 1761 (Ms. New York Public Library, New York City); 2 W. Smith, The History of the Province of New-York 243, 251 (M. Kammen ed. 1972).

1492 Journal of the Votes and Proceedings of the General Assembly of the Colony OF NEw YORK 1691-1765, at 653 (1764-1766). [hereinafter cited as JourN. Assemb. N.Y.].

${ }^{150}$ Letter from Lt. Gov. Colden to Board of Trade, Apr. 15, 1761, in 7 Doc. ReL. Col. Hist. N.Y., supra note 143, at 462 and in 1 COLden LETTER Books 79-80 (1877). The bill had been read a second time and committed to a Committee of the Whole House. 2 Journ. Assemb. N.Y., supra note 149, at 653. See also Letter from Lt. Gov. Colden to Board of Trade, Sept. 25, 1761, in 7 Doc. ReL. CoL. Hist. N.Y., supra note 143, at 470 for the private discourse of Colden on this subject with the Speaker and others at the first meeting with the Assembly.

${ }^{151}$ The act was entitled "An Act providing that Judges of the Supreme Court shall have their Commissions during good Behavior." 2 JourN. ASSEMB. N.Y., supra note 149, at 659-62. Colden, commenting on the bill to the Board of Trade, stated that the bill was contrary to his 39 th instruction (1 RoYal INSTRUCrIons, supra note 41, at $\$ 513$ ), and that the dependence on the people for subsistence, stemming from provision of salaries from year to year at the Assembly's pleasure, rather than on a fixed basis, might be highly prejudicial to the rights of the Crown and enforcement of the Acts of Trade. Letter from Lt. Gov. Colden to Board of Trade, June 2, 1761, in 7 Doc. ReL. 
Colden in Council for renewal of their commissions (continued beyond the King's death by royal proclamation) during good behavior. Although the Council had seen the prohibitory instruction, it probably would have advised granting such commissions nevertheless, had Colden not postponed consideration of the matter. ${ }^{152}$ Realizing that a return to the subject was inevitable and wishing to avoid administrative friction, Colden felt obliged to accede to the legislative will. He hoped that the measure might at least be tempered by a provision for permanent judicial salaries. ${ }^{153}$ During the summer, opposition to Colden intensified as news arrived of the unpopular appointment of Benjamin Pratt of Boston as Chief Justice. ${ }^{154}$ At the next session of the Assembly in September, the same bill, reintroduced, again passed both houses. Colden again withheld assent, awaiting directions from the Board of Trade. ${ }^{155} \mathrm{He}$ allegedly learned in early October that the judges intended not to act until their commissions were renewed with tenure during good behavior. Fearing a cessation of justice, Colden again warned the Board of Trade of the pressure for compliance, notwithstanding that the desired independence of the Assembly as well as of the King was not secured. ${ }^{156}$

Col. Hist. N.Y., supra note 143 , at 467 and in 1 COLDEN LETTER Books 89-90 (1877).

See also Letter from Lt. Gov. Colden to Sec'y Pitt, Sept. 24, 1761, in 1 id. 116-17.

${ }^{152}$ Letter from Lt. Gov. Colden to Board of Trade, Aug. 12, 1761, in 7 Doc. ReL.

Col. Hist. N.Y., supra note 143, at 468 and in 1 Colden Letrer Books 104-06 (1877).

See also 7 Doc. ReL. Col. Hist. N.Y., supra note 143, at 505, stating that the judges accepted tenure during pleasure on Colden's promise that if any future instruction authorized tenure during good behavior, he would accept their resignations and reappoint accordingly.

${ }^{153}$ The objection to such salaries was based on the absence of a perpetual fund for the purpose. Letter from Lt. Gov. Colden to Board of Trade, Aug. 12, 1761, in 7 Doc. Rel. Col. Hist. N.Y., supra note 143, at 468 and in 1 Colden LetTer Books 104-06 (1877). Colden had informed several Assembly members that provision for judicial salaries having the same continuance as the commissions would be a great inducement to him to assent to the bill and might excuse his action before the royal authorities. Letter from Lt. Gov. Colden to Board of Trade, Sept. 25, 1761, in 7 Doc. Rel. Col. Hist. N.Y., supra note 143 , at 470 .

${ }_{154} 4 \mathrm{Wm}$. Smith Papers, sub Nov. 24, 1761 (Ms. New York Public Library, New York City).

1552 Journ. Assemb. N.Y., supra note 149, at 665-68; Letter from Lt. Gov. Colden to Board of Trade, Sept. 25, 1761, in 7 Doc. ReL. Col. HIST. N.Y., supra note 143, at 469; Letter from I.t. Gov. Colden to Sec'y Pitt, Sept. 24, 1761, in 1 Colden LetTer Books 117 (1877). Colden was irritated further by the lawyers in the Assembly because they questioned the validity of the October, 1760 session in which Colden's salary had been fixed. $4 \mathrm{Wm}$. Smith Papers, sub Nov. 24, 1761 (Ms. New York Public Library, New York City).

${ }^{156}$ Letter from Lt. Gov. Colden to Board of Trade, Oct. 6, 1761, in 7 Doc. ReL. Col. Hist. N.Y., supra note 143, at 470-71 and in 1 Colden LeTTER Books 122 (1877). 
Matters were not as dark, however, as the beleaguered Colden represented them at home. In August, 1761 Pratt, the newly appointed Chief Justice, had sought information from Colden as to the tenor of his commission or of the mandamus therefor, leaving little doubt of his preference for tenure during good behavior. ${ }^{157}$ Colden, ignorant therein, had strongly urged Pratt to accept the office whatever the tenure, as a matter of public regard, and had assured him that efforts would be made to amend any unsatisfactory commission. ${ }^{158}$ Relying upon Colden's assurances that a commission quam diu se bene gesserit might be obtained later and that proper support would be obtained for the office, Pratt had accepted a commission "During Our Pleasure \& his Residence within our said Province."159 Pratt then hastened to assume office so that the Assembly would not refrain from settling a salary upon the office of Chief Justice. ${ }^{160}$ But before Pratt arrived, Chambers and Horsmanden had weakened in their stands and had accepted commissions during pleasure pro hac vice. Jones refused to accept such commission and did not sit in the October term. Although both Chambers and Horsmanden resigned their commissions after this term, their acceptance of commissions pro hac vice prevented a judicial stalemate. ${ }^{161}$

Governor Robert Monckton arrived in the province in November, 1761 and was shortly at odds with Colden. The Governor encouraged the Assembly to stand by his declaration in

${ }^{157}$ Pratt was not surprised by the colonial desire for a tenure secured in England after the Revolution of 1688 . He also pointed out the recent message of the King to Parliament on the subject. Under tenure during pleasure, "A Judge [was] liable to be broke by the Governor if he don't please him. And to be starved by' the Assembly if he don't please them." Letter from Benjamin Pratt Esq. to Lt. Gov. Colden, Aug. 22, 1761, in 6 ColdeN LETTERS AND PAPERS 68-69 (1923) (emphasis in original).

${ }^{158}$ Letter from Lt. Gov. Colden to Benjamin Pratt Esq., Sept. 7, 1761, in 1 Colden LETTER BOOKS 113-14 (1877).

${ }^{159}$ Letter from Benjamin Pratt Esq. to Lt. Gov. Colden, Oct. 13, 1761, in 6 CoLDEN LetTers and Papers 77, 81 (1923).

${ }^{160}$ Letter from Lt. Gov. Colden to Benjamin Pratt Esq., Oct. 12, 1761, in 1 ColdeN LETTER Books 123-24, 132 (1877).

${ }^{161} 4 \mathrm{Wm}$. Smith Papers, sub Nov. 24, 1761 (Ms. New York Public Library, New York City); 4 New York 22-23 in Chalmers Collection (Ms. New York Public Library, New York City). Colden alleged that Pratt prevented a failure of justice. Letter from Lt. Gov. Colden to Board of Trade, Jan. 11, 1762, in 1 Colden LetTer Books 148 (1877). But see Rough Minutes of the New York Supreme Court of Judicature (Oct. term, 1761) (Ms. Hall of Records, New York County Clerk's Office, New York City) (stating that only Chambers and Horsmanden sat). There was a partial failure of justice in that no criminal causes were heard. 4 Wm. Smith Papers, sub Nov. 24, 1761 (Ms. New York Public Library, New York City). 
Council that he would have granted commissions during good behavior and that it was wrong to refuse them. ${ }^{162}$ Early in December, the Assembly again passed a bill providing that $\mathrm{Su}$ preme Court judges should hold their commissions during good behavior, but the Council refused to concur without a clause making judicial salaries of the same continuance as the commissions. ${ }^{163} \mathrm{~A}$ plea by Colden for a larger allowance to the Chief Justice was then rejected by the Assembly as unnecessary to attract competent local talent. ${ }^{164}$ The Assembly also passed a bill providing that judicial salaries should be contingent upon possession of commissions during good behavior, hoping to force the retirement of Pratt for lack of funds and the appointment of a successor on more favorable terms in order to prevent a failure of justice. ${ }^{165}$ But Colden assented to the objectionable measure rather than have all officers of the government, including the judges, without salaries. ${ }^{166}$ Nevertheless, no commissions

${ }^{162}$ Letter from Lt. Gov. Colden to John Pownall Esq., Nov. 26, 1761, in 1 ColdeN LeTrer Books 138 (1877). Monckton allegedly did not desire to know Colden's reasons for refusal and did not speak to him on the matter. William Smith, Jr. wrote that Monckton favored commissions to the former judges on their old tenure, but that commissions to new officers should be durante bene placito. $4 \mathrm{Wm}$. Smith Papers, sub Nov. 24, 1761 (Ms. New York Public Library, New York City).

1632 Journ. Assemb. N.Y., supra note 149, at 670-71, 679; Letter from Lt. Gov. Colden to Board of Trade, Jan. 11, 1762, in 7 Doc. ReL. Col. HIST. N.Y., supra note 143, at 484 and in 1 COLDEN LETTER BOOKS 148-49 (1877). William Smith, Jr. alleged that the bill did not pass the Council because they, as well as the Assembly, were disinclined to Pratt as Chief Justice, and imagined that the bill, if passed, would be used as a pretext by Colden for swerving from the mandamus and giving Pratt a commission during good behavior. Since Pratt would then draw a salary, he might remain in the province. $4 \mathrm{Wm}$. Smith Papers, sub Dec. 24, 1761 (Ms. New York Public Library, New York City).

1642 Journ. Assemb. N.Y., supra note 149, at 681, 683; Letter from Lt. Gov. Colden to Board of Trade, Jan. 11, 1762, in 7 Doc. REL. Col. Hist. N.Y., supra note 143, at 484 .

${ }^{165}$ See Letter from Lt. Gov. Colden to Board of Trade, Jan. 11, 1762, in 7 Doc. Rel. Col. Hist. N.Y., supra note 143, at 484 and in 1 Colden LetTer Books 148-49, 151 (1877). Pratt believed that "at bottom the point in view is to compel the crown to appoint one of themselves Chief Justice." Letter from Chief Justice Benjamin Pratt to Sec'y Thomas Pownall, Jan. 7, 1762, in 6 Colden LetTers ANd Papers 115 (1923).

${ }^{166}$ Letter from Lt. Gov. Colden to Board of Trade, Feb. 11, 1762, in 7 Doc. ReL. Col. Hist. N.Y., supra note 143, at 489; 1 Colden LetTrer Books 159 . For the act, see 4 Colonial Laws of NEw YORK 550 (1894); for the legislative progress, see 2 Jours. AsEemB. N.Y., supra note 149, at 684-87. William Smith, Jr. wrote:

It was thought Colden would not pass it and so they [the Assembly] sent up the support bill. They were mistaken. While the support bill lay before the Council he came to them and urged their passage of it. Some members of the House privately entreated the Council not to pass it, but 'twas in vain, for they consented, Colden giving leave to enter on their minutes that it was at his earnest bequest. He had heard it was to be sent back for amendment and then kept there. 
were issued during good behavior. ${ }^{167}$

Meanwhile, the imperial authorities had not been idle. In a November 11, 1761 representation the Board of Trade stated that the question of judicial tenure had already been settled in Jamaica and Pennsylvania. With regard to English precedent, the Board asserted that independence of the English judiciary was attributable not only to the tenure provided, but also to the settlement of permanent salaries attractive to able personnel. In the colonies no such salaries were established, and it was thought necessary to preserve freedom of removal to improve the quality of judicial personnel. The Board strongly asserted the danger inherent in granting commissions during good behavior so long as judges were dependent on the will of the Assembly. ${ }^{168}$ The Board thereupon recommended, and the Council Board accordingly ordered, an instruction in the matter to all colonial Governors. ${ }^{169}$ As noted above, ${ }^{170}$ on December 12,1761 circular instructions were issued prohibiting assent to any act which regulated or ascertained tenure of judicial commissions in any manner whatsoever. Judicial commissions granted in the future were to be during pleasure only, in accordance with the long standing practice in the colonies. ${ }^{171}$

But the receipt of these instructions in February, 1762 did not defuse the issue in New York. A private offer by Colden to support a bill that restrained the Governor from removing judges without the consent of seven councillors, an address of the Assembly, or royal command, was not accepted. ${ }^{172}$ In March Pratt informed Nicoll, Speaker of the Assembly, of his intention

4 Wm. Smith Papers, sub Dec. 24, 1761 (Ms. New York Public Library, New York City). See also Journal of the Legislative Council of the Colony of New-York, 17431775 , at $1460-61$ (1861).

${ }^{167}$ The appointment of Robert Hunter Morris as Chief Justice during good behavior by Governor Hardy of New Jersey encouraged the similar demand upon Colden and made the anti-Coldenites confident that Governor Monckton on his return would comply with the Assembly demand. Colden had reason to think they had some assurances of this. Letter from Lt. Gov. Colden to Sec'y Pownall, Feb. 6, 1761, in 1 Colden LETTER BOOKS 162 (1877).

1687 Doc. Rel. Col. Hist. N.Y., supra note 143, at 474-75; 6 Colonial Records of North Carolina 582 (W. Saunderson ed. 1888) [hereinafter cited as Col. Rec. N.C.].

${ }^{169} 4$ APC, CoL., supra note 74, at $\$ 460$.

170 See text accompanying notes $136-39$ supra.

171 Royal Instructions, supra note 41, at § 514. See A.H. Basye, The LordS Commissioners of Trade and Plantations ... 1748-1782, at 112-14 (1925).

${ }^{172}$ Colden thought this offer could be reconciled with the additional instruction because the commissions would not be altered and the law could be repealed before it could take effect in any other admınistration. Letter from Lt. Gov. Colden to Board of Trade, Apr. 7, 1762, in 1 Colden LetTer Books 188-89 (1877). 
to leave the province. Noting that all other judges had either resigned their commissions or refused to sit, Pratt pointed out the necessity of providing for some other judge or judges. ${ }^{173}$ The Speaker replied that handsome judicial salaries were provided and granted in such manner that gentlemen not sinisterly motivated might accept them.

The Assembly, although aware of the consequences of failure of justice, did not feel any responsibility because it did not possess the power of judicial appointment. ${ }^{174}$ The anti-Colden faction saw several dangers latent in this threatened withdrawal, including the failure of justice, the appointment of inferior judges, and the creation of a precedent for an instruction gaining the force of a law without any opposition. This group agreed that the judicial tenure bill should be sent up again and, if blocked by the Governor or Council because of the instructions, it should be presented before the King in Council. ${ }^{175}$ Such action proved unnecessary, however, when Judges Horsmanden and Jones agreed to accept commissions during pleasure. ${ }^{176}$ The Board of Trade's subsequent censure of Colden, a staunch supporter of the royal prerogative, for his assent to the act providing for payment of officers' salaries ${ }^{177}$ provided an ironic touch to the controversy. The Board termed the salary act an "unprecedented and unjust attack upon the authority of the crown" and suggested that it be repealed. ${ }^{178}$ The act was accordingly disallowed. ${ }^{179}$

${ }^{173}$ Letter from Chief Justice Benjamin Pratt to Speaker of the Assembly, William Nicoll, Mar. 15, 1762, in id. 174-75. Colden had attempted to forestall this action. Letter from Lt. Gov. Colden to Chief Justice Benjamin Pratt, Mar. 7, 1762, in id. 171.

${ }^{174}$ Letter from Speaker of the Assembly, William Nicoll, to Chief Justice Benjamin Pratt, Mar. 16, 1762, in id. 175-76.

${ }^{175} 4$ Wm. Smith Papers, sub Mar. 13, 1762 (Ms. New York Public Library, New York City).

17625 N.Y. Council Mins., supra note 143 , at 422-33; 4 Wm. Smith Papers, sub Mar. 27, 1762 (Ms. New York Public Library, New York City); Letter from Lt. Gov. Colden to Gov. Robert Monckton, Mar. 30, 1762, in 1 Golden Letrer Books 183 (1877); Letter from Lt. Gov. Colden to Board of Trade, Apr. 7, 1762, in id. 189-90. Chambers continued to decline to act on any terms because of age and infirmities. Colden, in a December, 1765 account of the province, related that "by the Kings appointing Mr. Pratt, Chief Justice ... with a salary out of the quit rents, and the King confirming the former instructions by an additional instruction, the other judges submitted." Cadwallader Colden's Account of the State of the Province of New York, Dec. 6, 1765, in 7 Doc. ReL. Col. HIST. N.Y., supra note 143, at 797.

${ }^{177}$ See text accompanying notes 165-67 supra.

${ }^{178}$ Letter from Board of Trade to Lt. Gov. Colden, June 11, 1762, in 7 Doc. ReL. Col. Hist. N.Y., supra note 143, at 503-04; Representation of Board of Trade to the King, June 11, 1762, in id. 505-06.

${ }^{179} 4 \mathrm{APC}$, CoL., supra note 74 , at 807. 


\section{G. The Carolinas}

Judicial tenure also became a prominent issue in North Carolina during this period. In the preceding period of royal government in the colony, judicial tenure appears to have been uniformly during pleasure. ${ }^{180}$ In 1760 an act passed the Lower House establishing qualifications for appointees to the Supreme Court and providing that the associate judges should hold their offices quam diu se bene gesserint. ${ }^{181}$ This act allegedly was designed by a legislative junto to force judicial appointments from among their number and to render such appointees free from control by the Governor. ${ }^{182}$ Governor Arthur Dobbs questioned Chief Justice Berry and Attorney General Child whether it was consistent with his duty to pass such a bill contrary to his instructions and whether they believed the royal prerogative would be weakened by such assent. ${ }^{183}$ Both Berry and Child were of the opinion that the urgency of the judicial situation necessitated enactment of the measure and that no gubernatorial act could diminish the royal prerogative. ${ }^{184}$ Dobbs finally assented to the bill when it was passed for a two-year trial period until the royal pleasure was known further. ${ }^{18.5}$ The designs of the junto were frustrated, however, when three non-junto appointees were

${ }^{180}$ For examples of the commissions and mandamuses see 3 Col. REc. N.C., supra note 168 , at $136,490-94 ; 5 \mathrm{id} .403,962-64$. For an account of dismissals from office under Governor Dobbs, see Letter from Gov. Dobbs to Board of Trade, Aug. 3, 1760, in 6 id. 296-99. Dobbs alleged that he had never removed a justice without the advice and consent of the Council, and that he had removed only one not charged with injustice.

1814 APC, CoL., supra note 74 , at $\$ 465$.

182 See the account of Governor Dobbs in 6 Col. Rec. N.C., supra note I68, at 246. Compare the denial by the Assembly, 6 id. 986-87.

${ }^{183}$ Id. 334-35.

184 Id. 251-56. As to tenure during good behavior, Child stated:

[T] here are not wanting precedents of this nature in his Majesty's other provinces, occasioned no doubt by the spirit of particular times which had discerned the same reasons for having the justices commissions in America to depend upon good behavior as had occasioned those of the judges to be so framed at home.

Id. 255. In addition, appointees meeting the high qualifications of the act would not leave an established practice at the bar for an office held on so precarious a tenure as the pleasure of a governor.

${ }^{185} I d .247-48,408-09,420-21,425,428-29$. To the reluctant attitude of Dobbs, the Assembly retorted that "the Pertinacious Adherence to the Letter of an Instruction in a matter that could not have been had in Contemplation at the time it was framed when other Instructions in things of less moment to the Public have been easily got over to Answer Particular Purposes ... shews an unreasonable Desire to retain the Power of Appointing Judges for private Views and Partial Ends ...." Id. 417. 
found qualified and appointed Associate Judges of the Supreme Court. ${ }^{186}$

The act was reviewed in December, 1761 by the Board of Trade, which found both the qualificatory and tenure clauses objectionable. The Board found the irregularity of the tenure clause the more striking of its two objections because, pursuant to this clause, associate judges held office during good behavior while the Chief Justice, appointed by the Crown, held office only during the royal pleasure. ${ }^{187}$ The act was therefore disallowed by the King in Council. ${ }^{188}$ In a subsequent representation to the Board of Trade in May, 1763 the province agent asserted that the offending clause would not have been considered constitutionally subversive and restrictive of the prerogative if the North Carolina act had referred to the 1701 Act of Settlement and to the 1761 royal message to Parliament and the resulting statute that provided for continuation of judges in office notwithstanding the demise of the monarch. ${ }^{189}$ Judicial tenure lingered as an issue in North Carolina until the Revolution. ${ }^{190}$

When the question of tenure during good behavior was raised in South Carolina in 1766, Charles Garth, the colony's agent, advised from London that obviating popular dependency by enacting fixed judicial salaries was a prerequisite to securing the coveted tenure. ${ }^{191}$ Thus in 1768 an act was passed containing

${ }^{186}$ Letter from Gov. Dobbs to Board of Trade, Aug. 3, 1760, in id. 280. See also Letter from Gov. Dobbs to Board of Trade, July 21, 1760, in id. 268.

${ }^{187}$ Letter from Board of Trade to the King, Dec. 3, 1761, in id. 587-91. See also id. 627-28. For an October, 1761 commission to Chief Justice Berry, see id. 581.

${ }^{188} 4$ APC, Col., supra note 74 , at $\S 465$. See also J.P. Greene, The QUest for Power: The Lower Houses of Assembly in the Southern Royal Colonies, 1689-1776, at 338-41 (1963) [hereinafter cited as GreENE, The QUest For Power].

189 The representation also said that the Act of Settlement did not appear to be confined to subjects in England alone, but extended to subjects in general and that 13 Geo. 2, c. 7 (1739) was a declaration that subjects in the colonies were entitled to all the privileges of the people of Great Britain. 6 CoL. REC. N.C., supra note 168, at 986-87. For the royal message and 1 Geo. 3, c. 23 (1761) see note 34 supra and accompanying text.

${ }^{190}$ In 1774 Governor Josiah Martin wrote that it was a fixed principle with the Lower House not to grant the Chief Justice a permanent salary until the Crown appointed him during good behavior. See Letters from Gov. Martin to the Earl of Dartmouth, May 5, 1774, in 9 Col. Rec. N.C., supra note 168, at 992, and Oct. 16, 1775, in 10 id. 277.

191 Garth wrote to the Committee of Correspondence:

At present the greatest difficulty arises from the manner in which those officers have their salaries; if the salary was upon a fixt and certain establishment 1 verily believe we might succeed in obtaining their commissions during good 
a clause that provided salaries for the Chief Justice and the puisne justices whenever the King appointed them during good behavior. ${ }^{192}$ Although counsel Sir Matthew Lamb merely queried whether the provision might be derogatory to the royal dignity, ${ }^{193}$ the Board of Trade made a strong representation in this matter. The Board argued vigorously that granting these offices upon appropriate terms was a matter left by the constitution to the royal discretion, which could take into consideration the state and circumstances of the colonies. Considering the royal instructions in the matter, the Board deemed the provision in the South Carolina act unnecessary and improper. The provision was even more objectionable because it did not allow for removal by both legislative houses, a limitation on the independence of the judiciary in England which the Board believed

behaviour, before they are removed from a state of dependency upon the crown it is also expected they should be removed from any sort of dependency upon the people.

Letter from Garth to the Committee of Correspondence, Nov. 24, 1766, in Garth Correspondence 32 (Force Transcripts, Library of Congress). In the next year Garth applied for authority to promise a proper judicial establishment. Armed with such authority, Garth wrote that the ministry in England would take the whole matter into consideration. The agent cautioned that good behavior tenure had not yet been introduced into Ireland, but felt that a different result might be forthcoming than in the case of Pennsylvania. Letter from Garth to the Committee of Correspondence, Mar. 12, 1767, in id. $50-51$.

1923 Stat. at Large So. Car. 197-205. The act contained a suspending clause.

${ }^{193}$ Colonial Office Papers, CO 5/379/01 (Public Record Office, London). Before official action had had been taken upon the act Garth wrote:

Some accounts of it have reached Lord Hillsborough, particularly that part of it which relates to the conditional provision for the judges, who has expressed himself to me extreamely averse to advising the crown to grant the judges commissions during good behaviour, and from his manner of expressing himself I fear he will oppose it to the utmost, notwithstanding that I took care to inform his Lordship that his predecessor Lord Sherburne [Shelburne] had entertained a different idea of such a measure, and seemed to have but one difficulty, which by the present act I was given to understand would be found to be got over, by an ample and permanent fund established for the payment of the judges so as to render them entirely independent of the people.

Letter from Garth to the Committee of Correspondence, June 16, 1768, in Garth Correspondence 121-22 (Force Transcripts, Library of Congress). After the hearing Garth wrote that the matter had been prejudiced and that the idea of the desired alteration in judicial commissions was inadmissible with the present ministry. Letter from Garth to the Committee of Correspondence, Aug. 14, 1768, in id. 123; see also id. 124-26. Richard Cumberland, a clerk at the Board of Trade, who held by patent the Provostmarshalship of South Carolina, also had an interest in "the fate of the Act for the establishment of courts." See Letter from Cumberland to Roger Pinckney, his deputy in the province, Aug. 15, 1768, in $2 \mathrm{~W}$. Mudford, A Critical Examination of THE Writings of Richard Cumberland, Ese. app. 46-50 (1812) and in Documents Connected with the History of South Carolina 138-40 (P. Weston ed. 1856). 
should not be dispensed with in the colonies. For this reason, among others, the act met with disallowance. ${ }^{194}$

\section{H. Massachusetts Bay}

In Massachusetts Bay the commissions to the judges of the Superior Court of Judicature contained no provision as to tenure. Most judges and lawyers probably assumed that the commissions had been granted during pleasure, perhaps by analogy to the commissions to justices of the peace in England. ${ }^{195}$ On February 10, 1762 while Francis Bernard was Governor, a committee of the House of Representatives (to be joined by Council members) was appointed to inquire into the law establishing the Superior Court. The committee was instructed to consider the utility of the judges of the Superior Court holding their commissions during good behavior and having their salaries fixed. ${ }^{196}$ In a February 19th report the committee unanimously agreed that it would be of great utility if the judges of the Superior Court held their commissions during good behavior, in keeping with the Bill of Rights and the tenor of judicial commissions in England. The committee thought that this would also be pleasing to the King, who had praised tenure during good behavior in approving the 1761 act of Parliament which provided for the continuation of commissions during good behavior regardless of the death of the monarch. The committee felt, however, that it would not be a good idea to fix judicial salaries at that time. Although a bill was brought in, further consideration of the matter was postponed to the next session. ${ }^{197}$

${ }^{194} 5 \mathrm{APC}$, Col, supra note 74 , at $\S 86$ (1912). For the continued interest in the independence of the judiciary in South Carolina see W. H. Drayton, A Letrer from Freemen of South Carolina, to the Deputies of North-America, Assembled in the High Court of Congress at Philadelphia 10, 13, 19-20 (on independent judiciary and writs of assistance) (1774). See also GREENE, THE QUEST fOR POwer, supra note 188, at $400-02$.

${ }^{195}$ See the views of John Adams and William Brattle in their newspaper debate in 1773 (discussed at notes 213-15 infra). 3 Adams Works, supra note 37 , at 517, 520, 522, $533,559-61$.

19638 Journals of the House of Representatives of Massachusetts pt. II, at 239,242 (1762).

19744 Massachusetts Archives 502-04 (Ms. State House, Boston) [hereinafter cited as Mass. ARch.). The House hit upon the expedient of bringing in a bill to exclude judges of the Superior Court from seats in the Council; it failed passage by only six votes. E. Brennan, Plural Office-Holding in Massachusetts, 1760-1780, at 49-51 (1945). 
The preamble to the Townshend Revenue Act of 1767 declared that a revenue should be raised in America "for making a more certain and adequate Provision for defraying the charge of the Administration of Justice, and the Support of Civil Government," in those colonies where it should be found necessary. ${ }^{198}$ Although an amendment to the act had removed the taxes on many items, a three pence tax still remained on tea. ${ }^{199}$ The preamble was finally implemented by decisions of the ministry in Great Britain in early 1772 to make the Governor of Massachusetts Bay and, later in the year, the Superior Court judges independent of the popularly elected House of Representatives by granting them salaries out of the revenues drawn from America. ${ }^{200}$ Rumor of this last ministerial action generated a great clamor in the province, and, Governor Thomas Hutchinson reported, the newspapers were more inflammatory and treasonous than ever. ${ }^{201}$

At a Boston town meeting held on October 28, 1772 and moderated by John Hancock, several petitions were read concerning the report that the judges' salaries had been fixed by order of the Crown. The petitions decried the dangerous consequences thought to attend the establishment of royal salaries for the province judges. A committee, consisting of Samuel Adams, Dr. Joseph Warren, and Dr. Benjamin Church, was appointed to draft an address to the Governor asking for information on the matter. The address drafted by the committee on the afternoon of October 28 described the rumored order as contrary to the "ancient and invariable usage" and as "tending rapidly to complete the System of ... Slavery" which originated in the assump-

1987 Geo. 3, c. 46 (1767).

199 I0 Geo. 3, c. 17 (1770).

2003 Hutchinson, Hist. Massachusetrs-BAy, supra note 4, at 256-59; Additions to Thomas Hutchinson's 'History of Massachusetts Bay' (C. Mayo ed.) in 59 Ax. ANTIQuarian Soc'Y Proceedings 47, 49, 50 (1950). Governor Hutchinson was notified of the ministry's intention with respect to the judges' salaries by a June 6,1772 letter which suggested either reducing the number of judges or having the House make permanent provisions for the two junior judges. Hutchinson was doubtful that the House would cooperate and feared the danger of great inconveniences from a divided bench. See the copies or drafts of letters from Hutchinson, probably to Lord Hillsborough, Aug. 30 \& Sept. 4, 1772, in 27 Mass. ARCH., supra note 197, at 383, 385. (Hutchinson's letter books fill 3 volumes at the Massachusetts Archives; for those covering the years 1770-1774 see 27 Mass. ARCH. supra).

201 See his letters of Oct. $21 \& 23,1772$ in 27 Mass. Arch., supra note 197, at 39192, 396, 397-98. On the newspaper attacks see A. Schlesinger, Prelude to IndepenDENCE: THE NewSPAPER WAR ON BRITAIN, 1764-1776, at 146-48 (1958). 
tion by Parliament of the power to disburse the colonists' money without their consent. The address argued that, as the judges held their places during pleasure, "this Establishment appears big with fatal evils." 202 Hutchinson, on October 30, rejected the petition as constituting an improper request for information. ${ }^{203}$

The town then voted to petition the Governor to allow the General Assembly to convene at the time to which it was prorogued. Their petition labeled the rumored establishment contrary to the plain and obvious sense of the colony's charter and to the fundamental principles of the common law to which all British subjects, wherever dispersed throughout the empire, were indubitably entitled. The petition pointed out that in England everything humanly possible had been done to establish impartiality in judicial decisions not only between subject and subject, but between Crown and subject. Because the Massachusetts Superior Court was vested with powers as full and ample as those of England's courts of King's Bench, Common Pleas, and Exchequer, the goal of preserving its judges from the least supposable bias was of even greater importance. ${ }^{204}$ Hutchinson, however, saw no reason to have the Assembly meet and regarded the request as an invasion of the prerogative. ${ }^{205}$ Upon receipt of this reply the Boston town meeting resolved, on November 2nd, that they had the right to petition the King or his representatives for a redress of grievances. They authorized the establishment of a Commitee of Correspondence to disseminate their views on the rights of the colonists and the infringements and violations thereof, an important step in the events leading to the Revolution. ${ }^{206}$

202 Boston Town Records, 1770-1777, in 18 Boston Record Commissioners, REPORTS 88-90 (1887) [hereinafter cited as BOSTON TOWN RecoRdS]. James Otis discussed with John Adams whether it would constitute contempt to raise the question of the judges' salaries in open court. 2 Diary and Autobiography of John Adams 65 (L. Butterfield ed. 1961). For creation of the Boston Committee of Correspondence, see R.D. Brown, Revolutionary Politics in Massachusetrs: The Boston Committee of Correspondence and The Towns, 1772-1774, at 48-57 (1970) [hereinafter cited as Brown, Revolutionary Politics in Massachusetrs]. See also Letters from Samuel Adams to James Warren, Nov, 4 \& 27, 1772, Dec. 9, 1772, \& Dec. 28, 1773, Warren-Adams Letters, in 72 Massachusetrs Historical Society Collections 11-13, 14-15, 19-21 (1917).

${ }^{203}$ Boston Town Records, supra note 202, at 90.

${ }^{204}$ Id. $1-92$.

205 Id. 92.

${ }^{206}$ Id. 92-93. For the evidence of Hutchinson's failure to appreciate the significance of these events see his letters of November $10 \& 12,1772$ to England. 27 Mass. ARch., supra note 197, at 405, 412. For articles signed "A Freeholder" justifying the payment 
Accordingly, at a November 20, 1772 meeting, the freeholders and other inhabitants of Boston approved the text of three documents-in no way limited to the issue of judicial salaries. These were: (1) The State of the Rights of the Colonists and of Massachusetts Bay in particular, (2) the List of the Infringements and Violations of those Rights, and (3) a Letter of Correspondence with the other Towns. ${ }^{207}$ Among the rights of the colonists as subjects was an independent judiciary- "independent as far as possible of Prince or People." ${ }^{208}$ The statement of infringements and violations, noting the report that the Crown would pay the salaries of the judges of the Superior Court, commented that:

This will if accomplished compleat our slavery. For if taxes are raised from us by the Parliament of Great Britain without our consent, and the men on whose opinions and decisions our properties liberties and lives, in a great measure depend, receive their support from the Revenues arising from these taxes, we cannot, when we think on the depravity of mankind, avoid looking with horror on the danger to which we are exposed? The British Parliament have shewn their wisdom in making the Judges there as independent as possible both of the Prince and People, both for place and support: But our Judges hold their Commissions only during pleasure; the granting them salaries out of this Revenue is rendering them dependent on the Crown for their support. The King upon his first accession to the Throne, for giving the last hand to the independency of the Judges in England, not only upon himself but his Successors by recommending and consenting to an act of Parliament, by which the Judges are continued in office, notwithstanding the demise of a King, which vacates all other Commissions, was applauded by the whole Nation. How alarming must it then be to the Inhabitants of this Province, to find so wide a difference made between the Subjects in Britain and America, as

of fixed judicial salaries by the Crown, thus lessening the judges' dependence on the people, see The Massachusetts Gazette: and the Boston Weekly News-Letter, Nov. 5 \& $19,1772$.

${ }^{207}$ Boston Town Records, supra note 202, at 93-108. See also Hutchinson's letter to Thomas Gage, Mar. 7, 1773, explaining how the meeting progressed from judicial salaries to independence of Parliament. 27 MAss. ARCH., supra note 197, at 461-62.

${ }^{208}$ Boston Town ReCords, supra note 202, at 98. 
the rendering the Judges here altogether dependent on the Crown for their support. ${ }^{209}$

The Letter of Correspondence, after an introductory expression of alarm "at the plan of Despotism, which the enemies of our invaluable rights have concerted," launched into the matter of judicial salaries, as follows:

But, when in addition to the repeated inroads made upon the Rights and Liberties of the Colonists, and of those in this Province in particular, we reflect on the late extraordinary measure in affixing stipends or Salaries from the Crown to the Offices of the Judges of the Superior Court of Judicature, making them not only intirely independent of the people, whose lives and properties are so much in their power, but absolutely dependent on the Crown (which may hereafter, be worn by a Tyrant) both for their appointment and support, we cannot but be extremely alarmed at the mischievous tendency of this innovation; which in our opinion is directly contrary to the spirit of the British Constitution, pregnant with innumerable evils, and hath a direct tendency [t]o deprive us of every thing valuable as Men, as Christians and as Subjects, entitled, by the Royal Charter, to all the Rights, liberties and privileges of native Britons. Such being the critical state of this Province, we think it our duty on this truly distressing occasion, to ask you, What can withstand the Attacks of mere power? What can preserve the liberties of the Subject, when the Barriers of the Constitution are taken away? ${ }^{210}$

A report of the proceedings of the town meeting was printed and widely disseminated. The letters of correspondence sent from Boston evoked comparable resolutions in over one hundred towns in the province. ${ }^{211}$ At a December 14,1772 meet-

209 Id. 102.

$210 \mathrm{Id}$. 106. For a Mar. 23, 1773 vindication of the town against various charges by Hutchinson relating to the Nov. 20 meeting, see id. 120-25. Compare Hutchinson's Feb. 24, 1773 letter to John Pownall on the contisued inflammation of the minels of the people by incendiaries on the subject of judicial salaries. 27 Mass. Arch., supra note 197. at 457. See also the Mar. 9, 1773 letter to Lord Dartmouth. Id. 463.

213 Hutchisson, Hist. MASSAchusetts-BAY, supra note 4, at 259-65. For various town resolutions and instructions sce The Massachusetts Gazette: and the Boston Weekly News-Letter, Nov. 26, Dec. 4, 17, 24 \& 31, 1772; Jan. 14 \& 21, 1773. See also 
ing the freeholders and inhabitants of Cambridge voted instructions to their representative in the House containing the following passage:

[I]n the midst of our distress, we are still further alarmed with seeing the governor of the province made independent of the people, and the shocking report that the judges of the superior court of judicature, and other officers, have salaries affixed to their offices, dependent on the crown and ministry, independent of the grants of the commons of this province. By this establishment, our lives and properties will be rendered very precarious; as there is the utmost danger that through an undue influence the streams of public justice will be poisoned. Can we expect the scales will be held equal between all parties? Will such judges be unmoved by passion or prejudice, fear or favor? What a miserable situation will the man be in, under a corrupt administration, who shall dare to oppose their vile measures? Must he not expect to feel the keenest resentment of such administration, by judges thus bribed to pursue the plan of the ministry? ${ }^{212}$

The Cambridge meeting and resolves were significant because they sparked publication in the Boston press of a series of letters by William Brattle and John Adams canvassing the nature of judicial tenure in England and in Massachusetts Bay. ${ }^{213}$ Brattle, a Tory who had opposed the action taken at the town meeting, attempted to blunt the impact of the proposed payment of judicial salaries by the Crown by advancing the view (with little citation of authority) that the judges of the Superior Court enjoyed tenure during good behavior. ${ }^{214}$ Adams, making an extended review of the problem of judicial tenure in England, countered by maintaining that the judges of the Superior Court

the mocking resolutions of the fictitious town of "Loyalty" in the Apr. 22, 1773 issue, and the instructions to the Boston representatives in the May 6, 1773 issue. A collection of original town resolutions is in the Bancroft Collection, New York Public Library, New York City. See also J. Hosmer, The Life of Thomas Hutchinson 243, 244-46, 249-50 (1896).

2123 ADAMS WoRks, stpra note 37 , at 514-15.

213 The letters are reprinted, with some omissions and inaccuracies in transcription, in id. 516-74.

214 The letters of Brattle, which appeared in the Massachusetts Gazette: and the Boston Weekly News-Letter on Dec. 31, 1772 and in the Boston-Gazette, and CountryJournal on Jan. 25, 1773, are at 3 AdAMS Works, supra note 37, at 516-19, 531-36. 
were commissioned during pleasure and that judicial commissions during good behavior were void at common law in the absence of parliamentary establishment. ${ }^{215}$ Whether or not Adams was correct in his interpretation, which undermined the efforts of those who sought commissions during good behavior from the Crown, makes little difference. His articles on the eve of the Revolution served to focus attention upon judicial tenure as an area of American rights and liberties. ${ }^{216}$

When the House met in early 1773 and voted the salaries of the Superior Court judges, Governor Thomas Hutchinson, awaiting warrants from the Crown and concerned that the judges might be paid twice for the same period of service, delayed giving his assent. ${ }^{217}$ Pressed for the reasons for the delay, Hutchinson finally informed the House, on February 4, that the King had ordered that salaries be allowed the justices of the Superior Court. ${ }^{218}$ On February 12 the House, in a message to the Governor, declared that no judge with due regard for justice or for his own character would choose to be placed in the position of undue bias that would result from accepting, and becoming dependent on, salaries from the Crown; that the King in making the order must have been misinformed; and that the House was more and more convinced of the existence of a design by the administration to subvert the constitution and introduce arbitrary government in the province. The message ended by demanding an assurance that the justices would refuse to accept support in a manner so obnoxious to the disinterested and judicious part of the good people of the province, and so

215 The seven letters of Adams which appeared in the Boston Gazette, and Country Journal on Jan. $11,18 \& 25$, and Feb. $1,8,15 \& 22,1773$, are printed in 3 ADAMS Works, supra note 37, at 519-30, 536-74. For Adam's version of the origin of the controversy with Brattle see 2 Diary and Autobiography of John Adams 77-78 (L. Butterfield ed. 1961). See also G.S. Wood, The Creation of the American Republic, 1776-1787, at 294-95 (1969).

216 Curiously muted in the Brattle-Adams debate and in other discussions was the fact that juries in Massachusetts Bay were traditionally regarded as empowered to find both the facts and the law, a substantial restraint upon the judiciary, in theory at least.

217 Journal of the Honorable House of Representatives of His Majesty's Province of the Massachusetts-Bay . . Begun . . The Twenty-seventh Day of MAY . . 1772, at 168, 196, 204, 206 [hereinafter cited as J. House ReP. MASS. BAY 1772]; 27 Mass. ARch., supra note 197, at 405 . Hutchinson sent a circular letter to the judges on February 5 seeking assurances that they would not accept a salary from the General Court for any salary period covered by a Crown warrant. Id. 444-45. For the warrants issued to Massachusetts officials see Dickerson, Use Made of the Revenue from the Tax on Tea, 31 N. ENG. Q. 232, 240-41 (1958).

${ }^{218} \mathrm{~J}$. HouSE REP. MASS. BAY 1772, supra note 217, at 207. 
utterly inconsistent with the safety of the rights, liberties, and properties of the people. ${ }^{219}$ Four days later a second message pressed for an answer on the salary issue. ${ }^{220}$

When Hutchinson replied that he was unable to inform the House that the judges had refused or would refuse to accept support from the Crown, the House passed resolutions granting the judges salaries on a quarterly basis for the ensuing year. ${ }^{21}$ When Hutchinson failed to assent to these salary grants, the House reached several resolves. ${ }^{222}$ After a preamble characterizing the Townshend Revenue Act as an unconstitutional invasion of the charter and emphasizing that the independence of the judiciary was essential to the impartial administration of justice, the House resolved that: (1) making judges independent of grants of the people and altogether dependent on the Crown (which they would be if they accepted salaries from the Crown while holding commissions during pleasure) was unconstitutional and destructive of that security which every good member of civil society should be guaranteed under the laws and was the direct opposite of the practice in Great Britain; (2) the dependence of the judges on the Crown for support, especially those commissioned during pleasure, tended to subvert justice and to introduce oppression and despotic power; and (3) a justice holding his commission during pleasure, who accepted or depended on the Crown for support, would reveal that he did not have a proper sense of the importance of an impartial administration of justice, that he was an enemy to the court, and that he wished to permit the establishment of an arbitrary government in the province. ${ }^{223}$

In June, 1773, after repeating the substance of the March 3 resolutions, the House resolved that the judges had the duty to declare whether they would receive grants from the General Assembly or support from the Crown, and that the House had the indispensable duty to impeach before the Governor and Council those refusing to make such declarations. ${ }^{224}$ Matters fi-

${ }^{219} \mathrm{Id}$. 224. Many of the messages exchanged by Hutchinson and the House are printed in SPEECHES OF THE GOVERNORS OF MASSACHUSETTS, FROM 1765 TO 1775: AND the Ansivers of the House of Representatives to the Same (A. Bradford ed. 1818).

${ }^{220} \mathrm{~J}$. House ReP. MASS. BAY, supra note 217 , at 228, 241-42.

221 Id. 243, 246, 248.

${ }^{222}$ Id. 252, 255, 265, 280-83.

223 Id. 280-83.

224 Journal of the Honorable House of Representatives of his Majesty's 
nally came to a head in February and March of 1774. All the judges except Chief Justice Peter Oliver, a high Tory, capitulated to the pressure of the House and declared that they would not receive support from the Crown. ${ }^{225}$ On February 11 the House, characterizing receipt of Crown support as contrary to the charter and constitution of the province and obnoxious to the people of the province, resolved that Oliver was totally disqualified to hold office. A remonstrance and petition for Oliver's removal from office was submitted to the Governor and Council, but Hutchinson declined the request. ${ }^{226}$ The House then resolved, on February 22, that it was highly improper and contrary to precedent for the Chief Justice to sit even if the order for his removal had not actually passed. ${ }^{227}$

On February 24 the House drew up articles of impeachment for high crimes and misdemeanors against Oliver, which were laid before the Governor and Council. ${ }^{228}$ Hutchinson retorted that the Governor and Council lacked jurisdiction and that the articles should be tried in an established court. ${ }^{229}$ The House disagreed with this conclusion and vainly presented revised articles to the Council. ${ }^{230}$ Finally admitting defeat, the House resolved on March 9 that it had done all it could in the matter and directed that its conduct be given publicity in other colonies and that its agent in London, Benjamin Franklin, be notified of its

Province of the Massachusetrs-Bay . . Begun . . . The Twenty-sixth Day of May ... 1773, at 76, 86-88, 94 [hereinafter cited as J. House ReP. Mass. BAY 1773]. See also Benjamin Franklin's Rules for Reducing a Great Empire to a Small One, Presented to a Late Minister [Lord Hillsborough], in 6 Works of Benjamin FrankLin 204, 211-12 (J. Bigelow ed. 1904). For some references to an independent judiciary in the pamphlet literature see [J. Allen], The American Alarm, or The Bostonian Plea, For the Rights, and Liberties, of the People 10-11, 27-28, 33 (1773) and, by same author, AN Oration on THE Beauties OF Liberty, OR THE Essential Rights of the AMERICANS 46-50, 61 (1773). For grand jury challenges to the judges of the Superior Court to declare their intentions with respect to stipends from the Crown, see Brown, Revolutionary Politics in MASSACHusetTs, supra note 202, at 151-52.

${ }^{225} \mathrm{~J}$. House ReP. MASS. BAY 1773, supra note 224, at 113, 117-18, 133-35, 136-39.

${ }^{226}$ Id. 146-51, 159. The House sought to compel Hutchinson to take the advice of the Council on the remonstrance and petition, claiming that it was contrary to the charter not to do so. Id. 162-63, 167-68, 172-73.

${ }^{227}$ Id. $177-78,181-84$.

${ }^{228}$ Id. 194-201. John Adams, in his account of the judicial salaries dispute, took credit for first suggesting impeachment of the judges. 3 Diary aNd AutoBIograpHy of John Adams 297-302 (L. Butterfield ed. 1961). See also 2 id. 88-89.

${ }^{229}$ J. House ReP. MASS. BAY 1773, supra note 224, at 202-06. For the Council's reaction to the Governor's stand see The Massachusetts Gazette: and the Boston Weekly News-Letter, Mar. 17, 1774.

${ }^{230} \mathrm{~J}$. HOUSE ReP. MASS. BAY 1773, supra note 224, at 211-17, 232-36. 
stand.$^{231}$. Administration of justice by the Superior Court came to a halt in September, 1774 when grand and petty jurors refused to serve while Oliver remained on the bench, even if he was not sitting. ${ }^{232}$

The imperial attitude toward judicial tenure hardened as the Massachusetts Government Act of May 20, 1774, ${ }^{233}$ one of the "Intolerable or Coercive Acts," was passed. That act provided that after July 1,1775 , upon every vacancy in the offices of the Chief Justice and judges of the Superior Court, the Governor was to have full power and authority to nominate and to appoint successors to such offices "who shall hold their commissions during the pleasure of his Majesty, his heirs and successors."

When Governor Thomas Gage, Hutchinson's successor, intervened in August, 1774, pursuant to the Massachusetts Government Act, to prohibit town meetings in Massachusetts Bay, the radical leaders turned to a series of county conventions to evade the restriction. ${ }^{234}$ These conventions culminated in the Suffolk County Convention held at Milton on September 9, 1774. More than seventy delegates, under the leadership of Dr. Joseph Warren, agreed upon the revolutionary Suffolk Resolves. Among other things it was resolved that "[S]o long as the judges hold their Places by any other tenure than that which the charter and laws of the Province direct, they must be considered as

${ }^{231}$ Id. 241, 243. For Oliver's version of the actions of the House see PETER Oliver's Origin and Progress of the American Rebellion: A Tory's View 107-11 (Adair \& Schutz eds. 1963). See also 1 The Diary and Letters of His Excellency Thomas Hutchinson, 111-14, 130-32, 137-41 (P.O. Hutchinson ed. 1884) for Hutchinson's version of his handling of the situation, and the encomium on Hutchinson in the Boston Evening-Post, May 31, 1774. Compare John Hancock's address to the people of Boston on the fourth anniversary of the Boston Massacre, Mar. 5, 1774. H. NiLES, CHronicles of The American Revolution 76, 79 (A.T. Vaughan ed. 1965).

2323 Hutchinson, Hist. Massachusetts-Bay, supra note 4, at 317-18; E. Washburn, Sketches of the Judicial History of Massachusetts 301-02 (1840). For resolutions of the grand jurors of Charlestown and Worcester County, see The Massachusetts Gazette: and the Boston Weekly News-Letter, Apr. 15 \& May 12, 1774. For refusals to serve at the Superior Court in Suffolk County, see the issues of Sept. 1 \& 8, 1774; for Salem see the issue of Nov. 17, 1774. For resolutions in Barnstable, affecting the county courts, from which appeals might be taken to the Superior Court, see the issue of Nov. 3, 1774. See also Letter from Samuel Cooper to Benjamin Franklin, Sept. 9, 1774, in 6 Works of Benjamin Franklin 352-53 (J. Bigelow ed. 1904); The Massachusetts Gazette: and the Boston Weekly News-Letter, Feb. $2 \&$ 23, 1775; H. Niles, Chronicles of The American Revolution 140-42.

${ }^{233} 14$ Geo. 3, c. 45 (1774).

23412 L.H. Gipson, The British Empire Before the American Revolution: The TrIUMPHANT EMPIRE 157 (1965). 
under undue Influence, and are therefore unconstitutional officers, and as such no Regard ought to be paid to them . . .."235 These Resolves came before the First Continental Congress assembled in Philadelphia on September 28. In sympathy with the suffering of their countrymen in Massachusetts Bay "under the operation of the late unjust, cruel and oppressive acts of the British Parliament" the delegates unanimously approved the Suffolk Resolves. ${ }^{236}$ The significance of the Resolves may be judged by their similarity to passages in the later Declaration of Independence.

The Declaration of Colonial Rights and Grievances of the First Continental Congress (October 1, 1774) concentrated upon the issue of judicial salaries rather than upon judicial tenure. The preamble related that by acts of Parliament "Judges, who before held only Estates at will in their Offices, have been made dependent on the Crown alone for their Salaries." Resolutions specifying acts of Parliament as infringements and violations of the rights of the colonists included the Massachusetts Government Act and the Townshend Revenue Act of $1767 . .^{237}$ In December, 1774 Franklin, still in London, drew up a seventeenpoint proposal for effecting a reconciliation between Great Britain and the colonies. Point twelve provided that all judges were to be appointed during good behavior, with equally permanent salaries, to be paid out of the revenues of the various provinces by appointment of the assemblies. If the judges were to be appointed during the pleasure of the Crown, then the salaries were to be during the pleasure of the assemblies. ${ }^{238}$

Within a few months the clash of arms at Lexington and Concord stilled all debates on judicial tenure and judicial salaries. Fittingly, the Declaration of Independence in 1776 , in enumerating the tyrannies of the King, set forth that, "He has

${ }^{235}$ Id. $157-58,245-46$. The resolutions appear in The Massachusetts Gazette: and the Boston Weekly News-Letter, Sept. 15, 1774. Resolution No. 5 was concerned with judicial tenure. See also J. CARY, JoSEPH WARREN 152-58 (1961). 1904).

${ }^{236} 1$ Journals of The Continental Congress, 1774-1789, at 31-41 (W. Ford ed.

${ }^{237}$ Printed in $i d .63-73$ and in 9 English Historical Documents: American Colonial Documevts to 1776, at 805-08 (M. Jensen ed. 1964).

${ }^{238} 6$ Works of Benjamin Franklin 450 (J. Bigelow ed. 1904); 7 id. 6-7, 49, 53, 59. For late debate on judicial salaries in Massachusetts, see The American Colonial Crisis: The Daniel Leonard-John Adamis Letters to the Press, 1774-1775, at 18 , 30-31, 145, 166-68 (B. Mason ed. 1972). 
made Judges dependent on his Will alone, for the tenure of their offices, and the amount and payment of their salaries." ${ }^{239}$

\section{The AFTermath}

The struggles in the colonial period over judicial tenure and judicial salaries were reflected in the constitutions adopted in most of the states and, later, in the Constitution of the United States. The Bill of Rights of the Massachusetts constitution of 1780 declared that "judges of the supreme judicial court should hold their offices as long as they behave themselves well; and that they should have honorable salaries ascertained and established by standing laws." The chapter on the judiciary so provided. Nevertheless, the Governor, with the consent of the Council, could remove the judges upon the address of both legislative houses. ${ }^{240}$ The New Hampshire constitution of 1784, presumably copied from the Massachusetts constitution, contained virtually identical provisions with respect to judicial tenure. The same power of removal was vested in the state's President. ${ }^{241}$ Rhode Island and Connecticut continued to operate under the framework of their colonial charters.

In the middle states, the New York constitution of 1777 provided for tenure during good behavior until the age of sixty for the chancellor, the judges of the Supreme Court, and the first judge of each county court. As in the case of other state officers, they could be impeached for "mal and corrupt conduct"

${ }^{239}$ For the drafting of the clause see C. Becker, The Declaration of IndePendence: A Study in the History of Political Ideas 145, 164, 178, 188 (1958).

2403 F.N. Thorpe, Federal and State Constitutions, Colonial Charters, and Other Organic Laws 1893, 1905 (1909) [hereinafter cited as Thorpe, Federal and State Constitutions]. The rejected constitution of 1778 in effect provided that all judicial officers hold their places during good behavior. The Popular Sources of Political Authority: Documents on the Massachusetts Constitution of 1780, at 189 (O. \& M. Handlin eds. 1966). For town reactions to judicial tenure in the attempted ratification, see id. $251,256,286,302,352,363-64$. For mention of tenure in the Address to the March, 1780 Constitutional Convention, see $i d .439$. For some of the town reactions on judicial tenure, salaries, and appointments in the process of ratifying the 1780 Constitution, see id. 490, 528, 534, 540, 548, 562, 588, 598, 623, 783, 785-87, $803-04,808,831,850,880-881$. See also the statement that about one-third of the voters approved the clauses relating to an independent judiciary. O. \& M. Handus, Commonwealth: A Study of the Role of Government in the American Economy: MAssachusetts, 1774-1861, at 28 (1947). To the same effect see Morison, The Struggle over the Adoption of the Constitution of Massachusetts, 1780, in 50 MassachusetTS Historical Society Proceedings 353, 392-93 (1917).

${ }^{241} 4$ Thorpe, Federal and State Constitutions, supra note 240 , at 2457, 2466. 
in office upon vote of two-thirds of the Assembly. ${ }^{242}$ Under the New Jersey constitution of 1776 judges of the Supreme Court were appointed by the Governor and Assembly for seven-year terms subject to removal if found guilty of misbehavior by the Council or if impeached by the Assembly. ${ }^{243}$ Similarly, under the Pennsylvania constitution of 1776 , judges were to be appointed for seven-year terms by the President and the Council and were to have fixed salaries. A judge was subject to impeachment by the Assembly for maladministration. ${ }^{244}$ Under the Delaware constitution of 1776 all judges or justices were to continue in office during good behavior. All officers were subject to removal on conviction of misbehavior at common law, on impeachment by the Assembly before the legislative council, or upon the address of the General Assembly. ${ }^{245}$ The Maryland constitution of 1776 provided that the chancellor and all judges should hold office during good behavior, removable either for misbehavior, on conviction in a court of law, or upon address of the General Assembly, provided that two-thirds of all members of each house concurred in such address. ${ }^{246}$

With regard to the southern states, the Virginia constitution of 1776 provided that judges of the several principal courts were to continue in office during good behavior. If judges of the General Court were accused by the House of Delegates of an offense against the state by maladministration, corruption, or other means that endangered the state, impeachment proceedings were to take place in the Court of Appeals. Impeachment proceedings against other judicial appointees were to be held in the General Court. ${ }^{247}$ Under the North Carolina constitution of 1776 judges of the Supreme Courts of law and equity, judges of the admiralty, and justices of the peace were to hold office during good behavior. Any judge offending against the State by maladministration, corruption, or violation of any part of the constitution, might be prosecuted upon impeachment by the

${ }^{242} 5$ id. 2634, 2635. Trial could take place in a court instituted for the trial of impeachments and the correction of errors.

2435 id. 2596.

2445 id. 3087, 3088. For the opposition to tenure during good behavior (for life) in Pennsylvania see Selsam, $A$ History of Judicial Tenure in Pennsyluania, 38 Drck. L. Rev. 168, $171-73$ (1934).

245 I Thorpe, Federal and State Constitutions, supra note 240, at 564, 566.

2463 id. $1689,1697$.

2477 id. 3817-18. 
General Assembly or presentment by the grand jury of any court of supreme jurisdiction. ${ }^{248}$ In South Carolina, the 1776 constitution provided that all judges of courts of law (except justices of the peace) were to be commissioned during good behavior, removable on address of the General Assembly and legislative council. ${ }^{249}$ The 1778 constitution continued the provision for commissions during good behavior but made these judges removable upon the address of the Senate and House of Representatives. For mal and corrupt conduct in office judges could be impeached by two thirds of the members of the House of Representatives, with trial by the Senate and such judges who were not members of the House. ${ }^{250}$ The 1777 Georgia constitution made no provision for judicial tenure; the 1787 document provided for three-year terms of office for Superior Court judges. ${ }^{251}$

The various plans for a national judiciary submitted to the Constitutional Convention meeting in Philadelphia in 1787 all provided that judges hold their offices during good behavior. ${ }^{252}$ The principal arguments related to the method of appointment or election of judges and to the method of removal from office. ${ }^{253}$ Article III, section 1 of the Constitution, agreed upon at the convention, provided that the judges of both the supreme and inferior courts hold their offices during good behavior. The surviving records of the debates at the various state ratifying conventions disclose relatively little discussion as to judicial tenure. ${ }^{254}$

An appropriate conclusion to this paper is afforded by the encomiums of Alexander Hamilton in The Federalist No. 78:

${ }^{248} 5$ id. 2791-93.

${ }^{249} 6$ id. 3246.

${ }^{250} 6$ id. $3253,3254$.

2512 id. 789.

${ }^{252}$ See Ziskind, Judicial Tenute in the American Constitution: English and American Precedents, 1969 SuP. CT. Rev. 135, 148-51.

253 I M. Farrand, The Records of the Federal Convention of 1787 (1911) 21-22, 116, 119-21, 128, 232-33, 236, 244, 292; 2 id. 37-38, 41-45, 71-72, 80-83, 116-17, $122,136,144-46,334,337,389,423,428-30,493,495,533,537,539,545,547,550$, 575-76, 590, 637. See also Goebel, Antecedents and Beginnings to $1801 \mathrm{ch}$. V, in 1 History of The Supreme Court of the United States (1971).

$2342 \mathrm{~J}$. Elliot, The Debates in the Several State Conventions on the AdopTION OF THE FEDERAL Constitution (1881) 348, 409 (New York); 446, 480-81, 489, 491, 514, 531-32, 539 (Pennsylvania); 550-51 (Maryland); 3 id. 205, 303, 325, 468, 517, 537, 552, 559, 563-64, 580 (Virginia); 4 id. 121, 172, 246 (North Carolina); 324-25 (South Carolina). 
According to the plan of the convention, all the judges who may be appointed by the United States are to hold their offices during good behaviour, which is conformable to the most approved of the state constitutions; and among the rest, to that of this state [New York]. Its propriety having been drawn into question by the adversaries of that plan, is no light symptom of the rage for objection which disorders their imaginations and judgments. The standard of good behaviour for the continuance in office of the judicial magistracy is certainly one of the most valuable of the modern improvements in the practice of government. In a monarchy it is an excellent barrier to the despotism of the prince: In a republic it is a no less excellent barrier to the encroachments and oppressions of the representative body. And it is the best expedient which can be devised in any government, to secure a steady, upright and impartial administration of the laws. ${ }^{255}$

Once secured, tenure during good behavior made the judiciary independent of the executive. The framers of the various constitutions were not intent upon making the judiciary independent of the legislative branch-"the people." The story of this struggle for independence is another and different chapter in the annals of the American judiciary.

255 The Federalist No. 78, at 522 (J. Cooke ed. 1961) (A. Hamilton). See also the views of Madison, id. 251-53, 325-31, 337, 341, and the further comments of Hamilton, id. $531-34,547$. 